Review

\title{
The regulation of cyclin DI degradation: roles in cancer development and the potential for therapeutic invention John P Alao*
}

Address: Department of Cell and Molecular Biology, Lundberg Laboratory, Gothenburg University, P. O. Box 462, S-405 30, Gothenburg, Sweden Email: John P Alao* - John.P.Alao@molbio.gu.se

* Corresponding author

This article is available from: http://www.molecular-cancer.com/content/6/1/24

This is an Open Access article distributed under the terms of the Creative Commons Attribution License (http://creativecommons.org/licenses/by/2.0), which permits unrestricted use, distribution, and reproduction in any medium, provided the original work is properly cited.

\begin{abstract}
Cyclin DI is an important regulator of cell cycle progression and can function as a transcriptionl co-regulator. The overexpression of cyclin DI has been linked to the development and progression of cancer. Deregulated cyclin DI degradation appears to be responsible for the increased levels of cyclin DI in several cancers. Recent findings have identified novel mechanisms involved in the regulation of cyclin DI stability. A number of therapeutic agents have been shown to induce cyclin DI degradation. The therapeutic ablation of cyclin DI may be useful for the prevention and treatment of cancer. In this review, current knowledge on the regulation of cyclin DI degradation is discussed. Novel insights into cyclin DI degradation are also discussed in the context of ablative therapy. A number of unresolved questions regarding the regulation of cellular cyclin DI levels are also addressed.
\end{abstract}

\section{Background}

The cyclin D1 proto-oncogene is an important regulator of G1 to S phase progression in many different cell types. Together with its binding partners cyclin dependent kinase 4 and 6 (CDK4 and CDK6), cyclin D1 forms active complexes that promote cell cycle progression by phosphorylating and inactivating the retinoblastoma protein (RB) [1-3]. More recent studies have demonstrated that cyclin D1 also functions as transcriptional modulator by regulating the activity of several transcription factors and histone deacetylase (HDAC3) (reviewed in [4]). This activity is independent of CDK4 activity. The cyclin D1 protein has been shown to be unstable with a short halflife ( $24 \mathrm{~min}$ ) [5,6] and is degraded mainly via the $26 \mathrm{~S}$ proteasome in a ubiquitin-dependent manner [6]. Early studies suggested that the Skp2 F-box protein might be involved in cyclin D1 degradation [7]. Recently, two further F-box proteins were identified in separate studies as playing major roles in targeting the cyclin for degradation $[8,9]$.

Cyclin D1 is important for the development and progression of several cancers including those of the breast, oesophagus, bladder and lung [10-19]. Overexpression of cyclin D1 has also been linked to the development of endocrine resistance in breast cancer cells [20-22]. Cyclin D1 overexpression is a common event in cancer but does not occur solely as a consequence of gene amplification. Rather, increased levels of cyclin D1 frequently result from its defective regulation at the post-translational level $[23,24]$. A number of therapeutic agents have been observed to induce cyclin D1 degradation in vitro [25-30]. These studies indicate that the induction of cyclin D1 degradation may offer a useful avenue for therapeutic intervention [25-32]. 
In this review, current knowledge on the regulation of cyclin D1 degradation is discussed with a particular emphasis on recent discoveries in this area. The roles of cyclin D1 as a regulator of cell cycle progression have been extensively reviewed $[1,4,15,33-37]$ and will only be mentioned in the context of its degradation. Here, the current knowledge on the regulation of cell cycle-dependent and drug induced cyclin D1 degradation is reviewed. The discovery of novel regulators of cyclin D1 stability $[8,9,27]$ and their impact on this area of research is also examined.

\section{Cell cycle phase-dependent degradation of cyclin DI}

Cyclin D1 levels begin to rise early in G1 and continue to accumulate until the G1/S-phase boundary when levels rapidly decline. The degradation of the cyclin is essential for the replication of DNA because acute overexpression of cyclin D1 in fibroblasts prevented S-phase entry [38,39]. Cyclin D1 has been shown to repress DNA replication by binding to proliferating cell nuclear antigen (PCNA) and Cdk2. The binding of cyclin D1 to PCNA directly inhibits DNA synthesis [38]. Initial studies by Diehl et al., [6] demonstrated that cyclin D1 turnover was dependent on threonine 286 (T286) phosphorylation and regulated by ubiquitin-dependent proteasomal degradation. Phosphorylation of cyclin D1 was enhanced by binding to CDK4 and mutation of T286 to alanine (T286A) resulted in greatly increased stability of the cyclin. These studies also showed that CDK4 is not required for T286 phosphorylation, indicating the involvement of an additional kinase. Glycogen synthase kinase $3 \beta$ (GSK3 $\beta$ ) was eventually identified as being capable of phosphorylating cyclin D1 on T286 and inducing its rapid turnover [5]. GSK3 $\beta$ was also shown to promote the redistribution of cyclin D1 from the nucleus to the cytoplasm. It had been noted previously, that cyclin D1 degradation at S- phase was accompanied by its relocation to the cytoplasm [33] while GSK3 $\beta$ levels were observed to increase in the nucleus specifically during S-phase [6]. In addition, the highly stable T286A mutant maintained a nuclear localization pattern throughout the cell cycle. Further work eebsequently demonstrated that phosphorylation of T286 facilitated cyclin D1 nuclear export by enhancing its association with CRM1, a nuclear exportin [40]. Together these findings suggested that GSK3 $\beta$-dependent phosphorylation of cyclin D1 mediated its nuclear export and rapid degradation within the cytoplasm. Since GSK3 $\beta$ is negatively regulated by the Ras- phosphatidylinositol 3 kinase - Akt pathway [41,42], these findings also linked cyclin D1 stability to mitogenic stimulation (see Figure 1 and 2). Based on their observations, Diehl et al., [5] predicted that the deregulation of phosphorylation dependent cyclin D1 degradation might contribute to the development of cancer. Further studies demonstrated that the constitutive overexpression of the T286A mutant but not wild type cyclin D1, resulted in formation of foci in late passage cells. Overexpression of cyclin D1 T286A also facilitated anchorage independent growth of NIH-3T3 cells in soft agar [40].

A number of recent findings have questioned the role of GSK3 $\beta$ in mediating cyclin D1 degradation. Guo et al., confirmed the role of T286 phosphorylation in mediating cyclin D1 degradation at S phase and demonstrated that the levels of phosphorylated protein are elevated during this phase of the cell cycle $[43,44]$. The authors reported however, that there was no change in the activity of GSK3 $\beta$, Akt or PI3K during S-phase and inhibition of GSK3 $\beta$ activity did not influence cyclin D1 phosphorylation or protein levels during the cell cycle. Similarly, GSK3 $\beta$ localization was not observed to vary with cell cycle expression in MCF-7 breast cancer cells and inhibition of GSK3 $\beta$ activity did not completely abolish cyclin D1 degradation $[26,45]$. The experimental evidence however, clearly shows that GSK3 $\beta$ can phosphorylate cyclin D1 and inhibition of this activity diminishes the efficiency of cyclin D1 degradation. The impact of differential experimental systems on the conflicting observations described in these studies remains uncertain. Further studies on the role of GSK3 $\beta$-dependent and independent (see below) cyclin D1 degradation will thus be required.

\section{GSK3 $\beta$-independent cyclin DI degradation}

Cyclin D1 degradation has also been shown to occur independently of GSK3 $\beta$. Studies by Germain et al., [46] demonstrated that the cyclin D1 T286A mutant is subject to ubiquitin-dependent degradation. Similarly, a mutant unable to bind CDK4 (cyclin D1-KE) was also ubiquitylated. Since cyclin D1 mutants lacking T286 and/or T288 were still susceptible to ubiquitylation and degradation, the authors proposed the existence of a second pathway that does not require phosphorylation on T286. Since cyclin D1 mutants that fail to bind CDK4 were also subject to ubiquitin-dependent degradation, it appears that this pathway may serve to regulate the cellular levels of free cyclin D1.

More recently, a novel arginine-directed protein kinase has been implicated in the regulation of cyclin D1 stability [47]. Mirk/Dyrk1b is active at G0 and early G1 phases of the cell cycle and phosphorylates cyclin D1 on T288. Knockdown of Mirk/Dyrk1b by siRNA oligos resulted in increased levels of cyclin D1 protein but did not affect mRNA levels. Furthermore, Mirk/Dyrk1b mediated cyclin D1 downregulation was not sensitive to inhibition by lithium chloride ( $\mathrm{LiCl})$, an inhibitor of GSK3 $\beta$. These findings suggest that Mirk/Dyrk1b may cooperate with GSK3 $\beta$ to regulate cyclin D1 levels [47]. Since cyclin D1 degradation occurs mainly at the G1/S phase boundary however, the impact of a kinase active only at G0/G1 is likely to be minimal in proliferating cells. On the other 

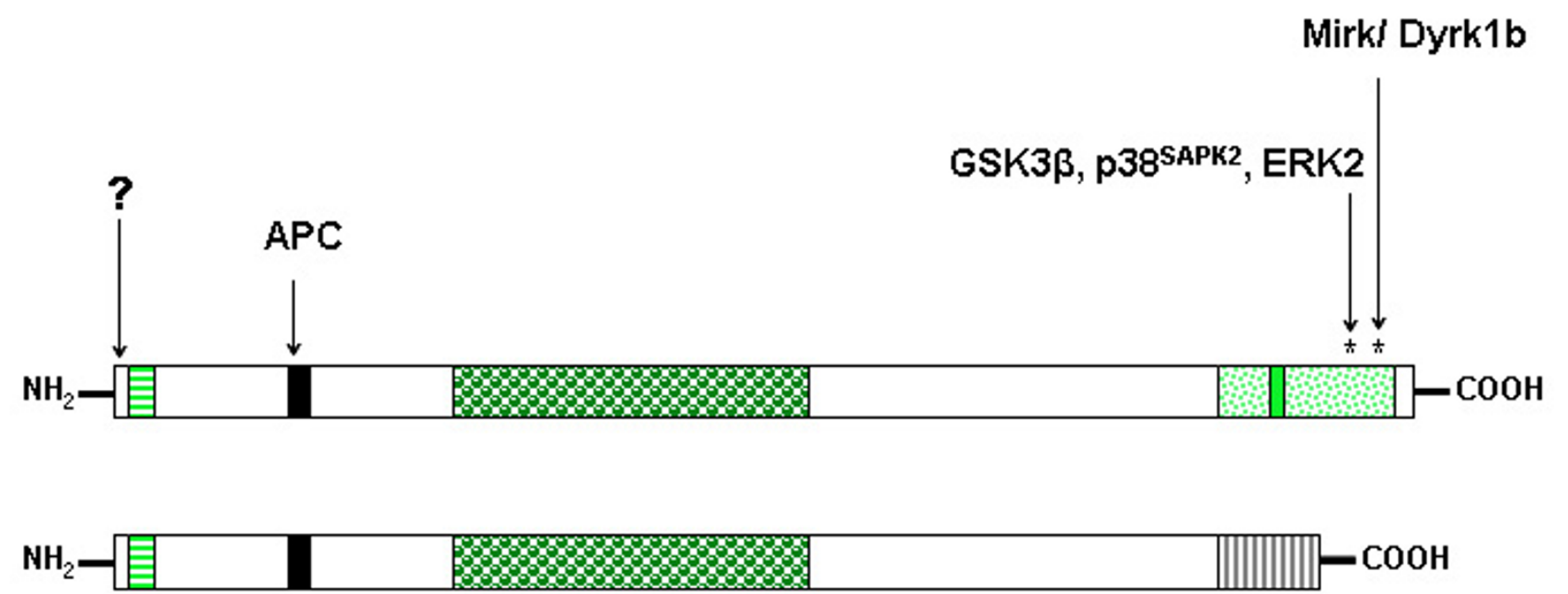

\section{9 = RB interacting site}

29- $32=\mathrm{Rx} \times \mathrm{L}$ motif

$56-145=$ Cyclin box

241 $-290=$ PEST motif

251- $255=\mathrm{LxxLL}$ motif

II $241-275=$ Intron 4 sequence

$* *=\mathrm{T} 286, \mathrm{~T} 288$

Figure I

Schematic representation of cyclin DI (top) and cyclin DIb (bottom) regulatory sequences. Cyclin DI stability is regulated by various mechanisms. The n-terminal region has recently been shown to be important for regulating stability [27]. (?) The mechanisms that regulate cyclin DI stability via the $n$-terminal remain to be clearly defined. The RxxL motif is required for APC (Anaphase Promoting Complex) mediated degradation following genotoxic insult [48]. GSK3 $\beta$ phosphorylates threonine residue 286 (T286) and regulates cyclin DI nuclear export and stability [5, 40]. P38SAPK2 and ERK2 have also been shown to regulate cyclin DI stability by phosphorylating T286 [9, 49, II4]. The threonine 288 residue (T288) has also been shown to regulate cyclin DI stability. Phosphorylation of T288 is mediated by the mirk/Dyrk Ib kinase [47]. In cyclin DIb, regulatory motifs and residues within the c-terminal region downstream of residue 240 are replaced by sequence from intron 4 of the CCNDI gene [62, 63]. Adapted from Knudsen, 2006 [13, 65].

hand, Mirk/Dyrk1b may serve to regulate cyclin D1 levels in situations where GSK3 $\beta$ activity is absent.

In mammalian cells, DNA damage, environmental stress and viral infection have also been shown to induce the ubiquitin-dependent degradation of cyclin D1. Genotoxic stress induces a $\mathrm{G} 1$ cell cycle arrest that is mediated by cyclin D1 degradation [48]. Following exposure to ionizing radiation (IR) cyclin D1 is rapidly degraded via the ubiq- uitin pathway. This degradation differs from the normal cell cycle related proteolysis, since it requires an $\mathrm{RxxL}$ destruction box within the $\mathrm{N}$ - terminus of cyclin D1. IR induced cyclin D1 degradation requires the AnaphasePromoting Complex (APC) but occurs independently of GSK3 $\beta$ [48]. Casanovas et al., [49] demonstrated that in addition to genotoxic stress, various chemically induced environmental stresses also induce cyclin D1 degradation in mantle cell lymphoma derived Granta 519 cells. 


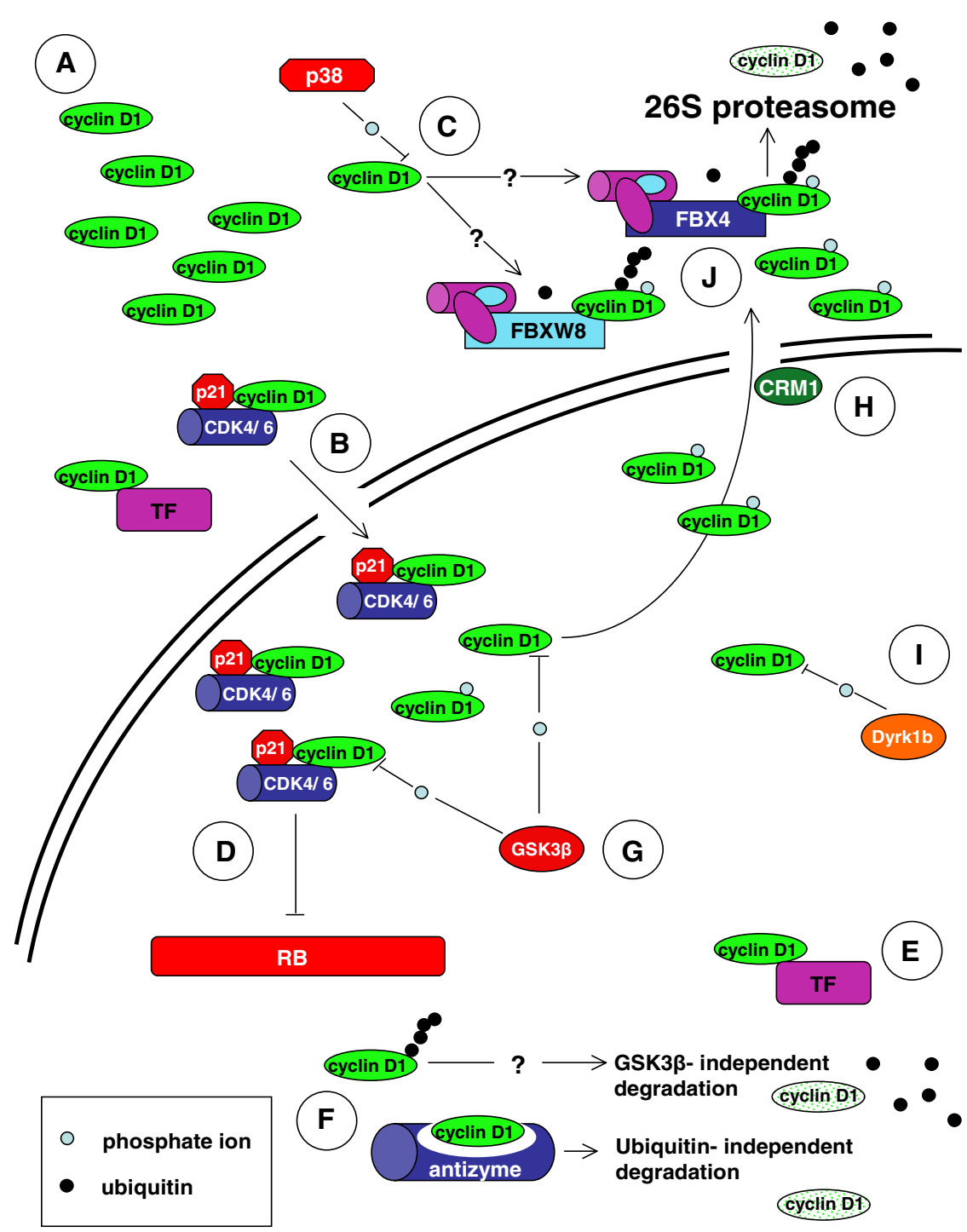

\section{Figure 2}

Regulation of cyclin DI degradation. A. Cyclin DI does not contain a nuclear localization signal (NLS) [I59] and its sequestration may result in accumulation within the cytoplasm $[45,75,76]$. B. Cytoplasmic cyclin DI is transported into the nucleus in association with its binding partners e.g CDK4 and possibly various transcription factors (TF) [I59-16I]. C. P38SAPK2 has been shown to phosphorylate cyclin DI on threonine residue 286 (T286) and induce its proteasomal degradation [49, II4]. It is unclear if the F-box proteins FBX4 and FBXW8 are involved in mediating P38SAPK2 induced cyclin DI degradation in the cytoplasm. D, E. Within the nucleus, active cyclin dependent kinase 4 (CDK4) or CDK6- cyclin DI complexes phosphorylate the retinoblastoma protein (RB) [2]. Cyclin DI can also influence the activity of various transcription factors independently of CDK4/6 [4]. F. Free cyclin DI is degraded through the ubiquitin dependent 26S proteasomal degradation pathway independently of glycogen synthase kinase $3 \beta$ (GSK3 $\beta$ ) [46]. Antizyme can also mediate cyclin DI degradation via the $26 \mathrm{~S}$ proteasome independently of ubiquitin [56]. G, H. GSK3 $\beta$ phosphorylates cyclin DI on T286 which facilitates its nuclear export by the exportin CRMI. GSK3 $\beta$ influences cyclin DI stability since the phosphorylated form of the cyclin is subsequently degraded within the cytoplasm [5, 6, 40]. I. Phosphorylation of T288 is mediated by the mirk/Dyrk I b kinase and can induce cyclin D I degradation [47]. J. FBX4 and FBXW8 ubiquitylate phosphorylated cyclin DI within the cytoplasm, targeting it for 26S proteasomal degradation $[8,9]$. 
Osmotic stress induced by sodium chloride $(\mathrm{NaCl})$, calcium chloride $\left(\mathrm{CaCl}_{2}\right)$ or magnesium chloride $\left(\mathrm{MgCl}_{2}\right)$ resulted in the rapid proteolysis of cyclin D1. Similarly, hydrogen peroxide $\left(\mathrm{H}_{2} \mathrm{O}_{2}\right)$ induced oxidative stress and sodium arsenite $\left(\mathrm{NaAsO}_{2}\right)$ also induced a rapid fall in cellular cyclin D1 levels. Specific inhibition of 26S proteasomes inhibited cyclin D1 degradation in all cases. Further studies demonstrated that the osmotic stress induced activation of $\mathrm{p} 38^{\mathrm{SAPK} 2}$ results in the phosphorylation of T286 and induces cyclin D1 degradation. Accordingly, specific inhibition of p38 $8^{\mathrm{SAPK} 2}$ with the p38 inhibitor SB203580 abolished osmotic stress but not $\mathrm{H}_{2} \mathrm{O}_{2}$ or $\mathrm{NaAsO}_{2}$ mediated cyclin D1 degradation. In vitro assays demonstrated that active immunoprecipitated p38 ${ }^{\text {SAPK2 }}$ from Molt-4 lymphoblastoid cells, phosphorylated cyclin D1 but not CDK2, CDK4 or cyclin A. Similar results were obtained using purified $\mathrm{p} 38^{\mathrm{SAPK} 2}$ and cyclin D1 phosphorylation was abolished by the addition of SB203580 in these assays. p38 $8^{\mathrm{SAPK} 2}$ was also shown to phosphorylate residues T156 and T286A in vitro. Inhibition of p38 $38^{\text {SAPK } 2}$ or mutation of cyclin D1 residue T286 to alanine abolished cyclin D1 ubiquitylation. It is thus clear, that osmotic stress induced by compounds such as $\mathrm{NaCl}$ results in the ubiquitin-dependent degradation of T286 phosphorylated cyclin D1. This pathway differs from that regulating normal $S$ phase associated degradation, since p38SAPK2 and not GSK3 $\beta$ mediates cyclin D1 phosphorylation. The p38 $3{ }^{\text {SAPK2 }}$ pathway is activated in response to various environmental stresses including UV radiation and histone deacetylase (HDAC) inhibitors (discussed below) [50]. Kidney derived cell lines exposed to high osmolarity transiently undergo cell cycle arrest $[51,52]$. Following exposure to environmental stress or DNA damage, the rapid degradation cyclin D1 may be necessary to ensure rapid cell cycle arrest. Indeed, the failure to accumulate cyclin D1 during G2 has been shown to prevent entry into a subsequent round of cell division $[53,54]$. The elevation of cyclin D1 levels in G2 is dependent on external stimuli. The regulation of cyclin D1 accumulation just prior to mitosis, serves to prevent further rounds of cell cycle progression under unfavourable conditions [54]. p38 $8^{\text {SAPK2 }}$ may thus play a central role in mediating cyclin D1 degradation following exposure to environmental stress or genotoxic insult.

Infection of HeLa cells by the Coxsackievirus group B3 (CVB3) has been shown to induce cyclin D1 degradation via the ubiquitin pathway [55]. Inhibition of GSK3 $\beta$ activity by LiCl did not prevent CVB3-induced cyclin D1 degradation. ODC-antizyme, a regulator of ornithine decarboxylase (ODC) has also been shown to target cyclin D1 for degradation via the 265 proteasome [56]. Interestingly, antizyme mediated cyclin D1 degradation occurs independently of ubiquitin or T286 phosphorylation. Upregulation of antizyme resulted in reduced levels of cyclin D1 and has been shown to inhibit the proliferation of transformed NIH3T3 cells and malignant keratinocytes. Similarly, tumour development and growth were also inhibited under conditions of increased antizyme activity [57-59]. It is clear that efficient cyclin D1 degradation can occur independently of GSK3 $\beta$ mediated T286 phosphorylation. The above cited studies also indicate that T286 phosphorylation independent degradation plays an important role in regulating cyclin D1 stability in response to environmental insults (see Figure 1 and 2).

\section{Cyclin DIb localization, stability and role in cancer development}

A cyclin D1 splice variant (cyclin D1b) has been identified in various cell lines and tissues [60-63]. An alternative splicing event within exon 4 , results in a 274 amino acid product lacking the C-terminal PEST domain and residue T286. Despite the loss of this region which is known to regulate cyclin D1 stability, the half-life of cyclin D1d is only slightly greater than that of full length variant (cyclin D1a). Similarly to the T286A mutant, cyclin D1b is constitutively nuclear but does accumulate to levels above those of cyclin D1a. Interestingly, cyclin D1b has been shown to be a poor activator of CDK4 and RB phosphorylation [63]. None the less, stable overexpression of cyclin D1b in $\mathrm{NIH}-3 \mathrm{~T} 3$ cells results in the formation of foci after 12 passages [63] and promotes anchorage independent growth [62]. Injection of late passage NIH-3T3 cells expressing cyclin D1b into SCID mice resulted in tumour formation [62]. Similar experiments using NIH-3T3 cells expressing cyclin D1a did result in tumour formation. Given the fact that cyclin D1b is relatively unstable and a poor inactivator of $\mathrm{RB}$, its transforming activity is surprising. It is possible that the constitutive nuclear localization, increased mobility or structural changes to the C-terminus facilitate cyclin D1b transforming activity [62-64]. The absence of a c-terminal PEST sequence or T286 residue suggests that the regulation of cyclin D1b is likely to be substantially different from cyclin D1a (see Figure 1 and 2). Both variants may however, be jointly regulated by phosphorylation independent degradation and other pathways $[27,46,56]$. Cyclin d1b has been reviewed in $[13,65]$.

\section{Role of the SCF complex in cyclin DI degradation}

The Skp- Cullin- F-box (SCF) complexes regulate protein stability by targeting substrate proteins for ubiquitindependent degradation. Cullin 1 (CUL-1) or cullin 7 (CUL-7) provides a scaffold that allows recruitment of the E3 ligase subunit RBX1/ROC1. SKP1 in turn binds the specificity determining component that comprises the Fbox protein family. F-box proteins are evolutionally conserved and multiple isoforms from several distinct classes occur in all cell types. The SCF complex has been extensively linked to the ubiquitin-dependent degradation of numerous cell cycle regulators including cyclin D1 [66- 
70]. Early studies indicated a role for CUL-1 and the SKP2 F-box protein in mediating cyclin D1 ubiquitylation [7]. Inhibition of SKP1, CUL-1 or SKP2 induced the accumulation of cyclin D1 and p21. Furthermore, both cyclin D1 and p 21 were shown to interact with CUL-1 in immunoprecipitates from cell lysates. These studies did not however, demonstrate a direct interaction between cyclin D1 and SKP2 or the in vitro ubiquitylation of cyclin D1 by SKP2.

More recently, the F-box proteins FBX4 and FBXW8 have been identified as bona fide mediators of cyclin D1 ubiquitylation using both in vitro and in vivo assays $[8,9]$. FBX4 recognition of cyclin D1 requires T286 phosphorylation and the presence of $\alpha \mathrm{B}$ crystallin. Both FBX 4 and $\alpha \mathrm{B}$ crystallin are required for the rapid ubiquitin-dependent degradation of T286 phosphorylated cyclin D1 and depletion of either component results in the increased stability and accumulation of cyclin D1 [8]. FBX 4 and $\alpha$ B crystallin are both cytoplasmic proteins. The nuclear export of T286 phosphorylated cyclin D1 during S phase thus facilitates association with the SCFFBX4- $\mathrm{\alpha B}$ crystallin $\mathrm{E} 3$ ligase complex. Importantly, a number of human cancer cell lines with high cyclin D1 levels were shown not to express $\alpha \mathrm{B}$ crystallin. Exogenously expressed $\alpha \mathrm{B}$ crystallin was able to restore the rapid degradation of cyclin D1 in the MCF-7 breast cancer cell line. Low or absent expression of $\alpha \mathrm{B}$ crystallin and FBX4 mRNA was also observed in numerous tumour samples from a diverse array of malignancies. Together these findings suggest that deregulated FBX4 activity and/or $\alpha \mathrm{B}$ crystallin expression may be responsible for the increase in cyclin D1 stability observed in some cancers [8].

An independent study by Okabe et al., [9] has identified FBXW8 as a second cyclin D1 E3 ligase. Interestingly, this study also identified the mitogen activated protein kinase (MAPK) ERK2 as a novel protein kinase capable of phosphorylating cyclin D1 on T286. ERK2 mediated phosphorylation of T286 requires a conserved D-domain (amino acid residues 179-193) within cyclin D1. In vitro assays demonstrated that ERK2 phosphorylates wild type but not D-domain deleted $(\Delta \mathrm{D})$ or T286A mutant cyclin D1 in vitro. Similarly, culture of HCT116 colon cancer cells with the MEK inhibitor U0126 extended the half life of cyclin D1 and abolished T286 phosphorylation. The study did not however, examine the effect of prolonged MEK inhibition by U0126 on cyclin D1 accumulation. In our studies, treatment of MCF-7 cells with U0126 resulted in decreased cyclin D1 protein levels following a $24 \mathrm{~h}$ exposure (J. P. Alao et al., unpublished observations). ERK2 mediated regulation of cyclin D1 stability may thus be cell line specific. The study by Okabe et al., [9] also identified FBXW8 as a second F-box protein capable of mediating cyclin D1 polyubiquitylation. Cyclin D1 associated with
Skp1, cullin (CUL1 and CUL7) and CDK4. FBXW8 interacted with cyclin D1 in a T286 phosphorylation-dependent manner and mediated its ubiquitylation in vitro. FBXW8 mediated ubiquitylation of cyclin D1 was enhanced by the presence of ERK2 and mutation of T286 to alanine (T286A) or deletion of the D domain abolished this activity. The siRNA mediated knockdown of CUL1, CUL7 and FBXW8 in HCT116, SW480, U-2 OS and T98 cancer cell lines resulted in the mainly cytoplasmic accumulation of T286 phosphorylated cyclin D1. Under these conditions, the half-life of cyclin D1 was also extended. The nuclear export of phosphorylated cyclin D1 during S phase facilitates its subsequent ubiquitylation by FBXW8 localized within the cytoplasm [9]. Interestingly, cyclin D1 accumulation following CUL1, CUL7 or FBXW8 siRNA was observed to inhibit the proliferation of HCT116 cells and coexpression of inducible T286A mutant abolished this effect. In contrast, knockdown of FBX 4 and $\alpha B$ crystallin enhanced the rate of $G 2$ to $S$ phase progression despite the accumulation of cyclin D1. Unlike SCFFBX4- $\alpha$ B crystallin, the FBXW8 complex is clearly expressed in various cancer cell lines. Studies on the relative expression levels of FBXW8 in matched tumour samples have not yet been reported [9]. Further studies are thus needed to dissect the relative roles of SCFFBX4- $\alpha$ B crystallin and FBXW8 in various cell lines and tissues.

\section{Ubiquitin- independent cyclin DI degradation}

The findings of an elegant study on the regulation of cyclin D1 ubiquitylation have recently been reported [27]. Cyclin D1 contains 18 lysines that serve as putative ubiquitylation sites. Feng et al., [27] expressed cyclin D1 mutants with single or multiple lysine to arginine substitutions in a human bronchial epithelial cell line. The effects of these mutations on all-trans-retinoic acid (RA) (discussed below) induced cyclin D1 polyubiquitylation and degradation were then investigated. In general, single substitutions had little effect on cyclin D1 stability. The joint mutation of lysine 112,114 or lysine residue 269 alone resulted in a modest increase in cyclin D1 stability but did not prevent polyubiquitylation [27]. The effective abolition of cyclin D1 ubiquitylation required the mutation of at least 17 out of the 18 possible lysine residues. The half-life of these mutants was increased by more than $50 \%$ when de novo protein synthesis was inhibited. Of interest is the observation that certain mutations stabilized cyclin D1 but did not affect its polyubiquitylation. Furthermore, a cyclin D1 mutant lacking all lysine residues exhibited a predominantly nuclear localization [27]. These mutants are none the less still susceptible to some form of degradation and their cellular levels are not above those of wild type cyclin D1. In fact, the study by Feng et al., (2007) [27] demonstrated that the N-terminal end of cyclin D1 plays an important role in regulating its stability. Ubiquitin independent pathways such as those medi- 
ated by antizyme [56] may thus play a crucial role in regulating cellular cyclin D1 levels. The effects of these mutants on cellular proliferation have not been reported.

\section{Microscopy vs. subcellular fractionation in studies on cyclin DI proteolysis}

Current models on cyclin D1 degradation assume a predominantly nuclear localization with the cytoplasm as the site of degradation. The reader is warned however, that discrepancies exist in regard to the actual cellular localization of cyclin D1. Subcellular fractionation or the selective purification of cellular organelles is a useful method for studying protein localization and redistribution within the cell [71]. Subcellular fractionation techniques have been employed in several studies on cyclin D1 degradation and localization [9,45,72-76]. Intriguingly, these studies suggest that the majority of cyclin D1 is localized within the cytoplasm of various cell lines. Conversely, immunofluorescence studies have consistently demonstrated a predominantly nuclear localization for cyclin D1 outside of $S$ phase $[33,40,43,77]$. The suggestion that cytoplasmic sequestration regulates cyclin D1 activity in postmitotic neurons, neonatal cardiomyocytes and cancer cell lines is partly based on experiments that involved subcellular fractionation techniques $[19,45,75,76]$. Importantly, the fractionation of mantle cell lymphoma (MCL) and multiple myeloma (MM) cell lines suggests that cyclin D1b localizes to both the nucleus and cytoplasm [73]. At present, the significance of the observations made in studies using subcellular fractionation remains unclear. It is also unclear if subcellular fractionation techniques can be reliably employed in studies on cyclin D1 localization. It has been proposed that a small protein like cyclin D1 might be released from the nucleus during the preparation of subcellular fractions [54]. The accurate normalization of protein levels or concentrations between different subcellular fractions also presents technical difficulties. A survey of the literature reveals however, that in contrast to cyclin D1 ( 34 kDa), the highest levels of small proteins like USF-1 ( 34 kDa), c-Fos ( 41 kDa), c-Jun ( 36 kDa) and CDK2 ( 34 kDa) occur in the nuclear fraction $[19,71,78]$. Cyclin D1 nuclear export also appears to be an active process that requires T286 phosphorylation/CRM1 binding [40] and the protein appears to be immobile within the nucleus [63]. Confocal microscopy analyses also suggested the predominantly cytoplasmic localization of cyclin D1 in MCF-7 cells, even though it appeared to be predominantly nuclear when the same antibody was used for wide-field microscopy [45]. Further studies will be required to validate the use of subcellular fractionation in studies on cyclin D1 localization and degradation. Such validation might be expected to substantially alter our view of how cyclin D1 is regulated at the post translational level in certain cell types.

\section{Drug induced cyclin DI degradation}

The importance of cyclin D1 in cancer makes it an attractive target for anti-cancer therapy and ablative agents are currently in development $[32,79,80]$. Several conventional and experimental anti-cancer agents have been observed to induce cyclin D1 degradation in a wide range of cancer cell lines. Additionally, several naturally derived compounds induce cyclin D1 degradation in cancer cells. Cyclin D1 degradation induced by these agents is not strictly dependent on T286 phosphorylation. The literature on the effects of various natural and synthetic compounds on cyclin D1 stability is reviewed below. For clarity, the cell lines, drug concentrations, proteasome inhibitors and rates of cyclin D1 degradation in the various studies are mentioned (see Table 1).

The retinoid receptors comprise a large family of nuclear receptors that regulate various cellular and physiological processes $[81,82]$. Retinoids inhibit the proliferation of cancer cells and prevent secondary tumour formation. The modulation of retinoid receptor activity thus presents an attractive therapeutic target (reviewed in [31,79]. All-trans retinoic acid (RA) has been shown to delay G1/S phase transition and negatively regulate cyclin D1 expression [29]. Treatment of immortalized human bronchial epithelial (BEAS-2B) cells with $4 \mu \mathrm{M}$ RA results in a rapid decline in cyclin D1 levels within 3-6 h. RA induced cyclin D1 degradation was abolished by specific inhibition of $26 \mathrm{~S}$ proteasomes using lactacystin. Treatment of NT2/D1 embryonal carcinoma cells with $10 \mu \mathrm{M}$ RA resulted in reduced cyclin D1 levels within 2 days of treatment [30] and was sensitive to the proteasome inhibitor LLnL (ALLN, Calpain inhibitor 1, N-acetyl-leucyl-leucyl-norleucinal, MG101). RA induced cyclin D1 degradation requires T286 phosphorylation since the T286A mutation abolished polyubiquitylation in vivo. It is noteworthy, that RA was considerably more effective at inducing cyclin D1 degradation in BEAS-2B cells (3-6 h) compared to NT2/ D1 cells $[29,30]$. Further studies demonstrated that receptor- nonselective retinoids but not carotenoids mediate the degradation of cyclin D1 via the ubiquitin pathway [83]. The effects of retinoids on cell proliferation and cyclin D1 stability thus appear to be dependent on retinoic acid receptor (RAR) $\alpha, \operatorname{RAR} \beta$ and the retinoid $\mathrm{X}$ receptor (RXR) but not RAR $\gamma$. Retinoid mediated cyclin D1 degradation has been proposed to underlie the chemopreventitive and antiproliferative activity of these compounds $[27,29,30]$.

Differentiation-inducing factor-1 (DIF-1) induces cyclin D1 degradation in human oral squamous cell carcinoma (SCC) and cervical cancer cell lines [84-86]. Differentiation-inducing factors (DIFs) are morphogens that were first identified in Dictyostelium where they regulate stalk differentiation $[87,88]$. DIF-1 induces G0/G1 cell cycle 
Table I: Compounds known to induce cyclin DI degradation in mammalian cell lines.

\begin{tabular}{|c|c|c|c|c|}
\hline Compound & Conc. & T286 dependent? a & Cell line & Proteasome inhibitor \\
\hline All-trans retinoic acid (RA) & $4-10 \mu \mathrm{M}$ & Yes & BEAS-2B, NT2/DI & Lactacystin, LLnLb \\
\hline Differentiation-inducing factor-I and 3 (DIF-I and DIF-3) & $30 \mu \mathrm{M}$ & Yes $^{c}$ & SCC, HeLa & MGI32 \\
\hline I-Methyl-4-phenylpyridinium ion (MPP+) & $300 \mathrm{nM}$ & Yes & MG63 & MGI32 \\
\hline hypothemycin & $0.5 \mu \mathrm{g} / \mathrm{Ml}$ & N.D. & NIH3T3-DT & Lactacystin \\
\hline O-methyl deoxybouvardin (RA-VII) & $100 \mathrm{nM}$ & N.D. & DLD-I & Lactacystin \\
\hline GL33I & $10 \mu \mathrm{M}$ & N.D. & CLI-5 & N-CBZ-L-L-L-AL \\
\hline Resveratrol & $300 \mu \mathrm{M}$ & N.D. & SW480 & $\operatorname{LLnL}^{\mathrm{b}}$ \\
\hline Diferuloylmethane (curcumin) & $25 \mu \mathrm{M}$ & N.D. & LnCap, various breast cancer derived & Lactacystin \\
\hline Lovastatin & $10 \mu \mathrm{M}$ & & PC-3-M & LLnL $b, d$ \\
\hline Aspirin & $5 \mathrm{nmol} / \mathrm{L}$ & $Y_{e s}{ }^{e}$ & SW480, HT-29 & MGI32 \\
\hline Cycloheximide & $50 \mu \mathrm{M}$ & No & MCF-7 & MGI32 \\
\hline 15-deoxy- $\Delta^{12,14}$ prostaglandin $J_{2}(\mathrm{PG} 2)^{f}$ & $5-20 \mu \mathrm{M}$ & N.D. & MCF-7 & MGI32, PSII \\
\hline Ciglitazone $\mathrm{f}^{\mathrm{s}}$ & $30-40 \mu \mathrm{M}$ & N.D. & MCF-7 & MGI32, PSII \\
\hline Troglitazone $e^{f}$ & $40 \mu \mathrm{M}$ & No & MCF-7 & MGI32, lactacystin, epoxomicin \\
\hline$\Delta 2-\mathrm{TGg}^{\prime}$ & $5 \mu \mathrm{M}$ & No & MCF-7 & MGI32, lactacystin, epoxomicin \\
\hline Rapamycin & $100 \mathrm{nmol} / \mathrm{L}$ & Yes & MCF-7, MDA-MB-468 & LLnLb \\
\hline Trichostatin A (TSA) ${ }^{\mathrm{h}}$ & $\mathrm{I} \mu \mathrm{M}$ & Yes/noi & MCF-7, MDA-MB-23I, KNRK & MGI32, ALLN, lactacystin, NLVSj \\
\hline $\begin{array}{l}\text { Sodium chloride }(\mathrm{NaCl}) \text {, calcium chloride }\left(\mathrm{CaCl}_{2}\right) \text {, } \\
\text { magnesium chloride }\left(\mathrm{MgCl}_{2}\right)\end{array}$ & $50 \mathrm{mM}$ & $\mathrm{Yes}^{\mathrm{e}}$ & Granta 519 & LLnL', lactacystin, MGI 32 \\
\hline
\end{tabular}

a) T286 phosphorylation requirement, b) LLnL (ALLN, Calpain inhibitor I, N-acetyl-leucyl-leucyl-norleucinal, MG I0I), c) Mirk/Dyrk Ib mediated T288 phosphorylation required, d) Lactacystin failed to abolish lovastatin induced cyclin DI degradation, e) P38SAPK2 mediated T286 phosphorylation, f) PGJ2, ciglitazone and troglitazone are PPAR $\gamma$ agonists, g) $\triangle 2$-TG is structurally related to troglitazone but lacks PPAR $\gamma$ agonist activity, h) TSA is a prototype HDAC inhibitor, i) partial requirement for GSK3 $\beta$ in TSA induced cyclin DI degradation, j) NLVS (NIP-leu ${ }_{3}$-vinyl sulphone)

arrest, in part by inducing the ubiquitin-dependent degradation of cyclin D1 [84]. The DIF-1 induced degradation of cyclin D1 is one of the most rapid reported to date, occurring within 30 to 60 minutes after exposure to $30 \mu \mathrm{M}$ of the compound. Inhibition of proteasome activity with MG132 abolished DIF-1 induced cyclin D1 degradation. DIF-1 activates GSK3 $\beta$ and causes it to relocate to the nucleus. Inhibition or siRNA mediated knockdown of GSK3 $\beta$ attenuated DIF-1 induced cyclin D1 degradation. Similarly, the T286A mutant was resistant to DIF-1 induced degradation, while the T288A mutant was partially resistant. DIF-1 thus induces cyclin D1 degradation in a manner dependent on the phosphorylation of T286 and T288 by GSK3 $\beta$ and Mirk/Dyrk1b respectively. Further studies have demonstrated that DIF-3 $(30 \mu \mathrm{M})$ induces cyclin D1 degradation in cancer cells similarly to DIF-1. DIF-3 activates GSK3 $\beta$ and Mirk/Dyrk1b in HeLa cells and the induction of cyclin D1 degradation requires phosphorylation of T286 and T288 [85].

$\mathrm{MPP}^{+}$(1-Methyl-4-phenylpyridinium ion) is an active metabolite of (1-Methyl-4-phenyl-1,2,3,6-tetrahydropyridine (MPTP), that inhibits proliferation and induces cytotoxicity in various cell types [89-91]. MPTP is used to induce experimental models of Parkinson's disease $[92,93]$. MPP+ induced cell cycle arrest but not apoptosis in MG63 osteosarcoma cells [94]. Doses as low $300 \mathrm{nM}$ induced near complete depletion of cyclin D1 within $4 \mathrm{~h}$ of treatment. Co-treatment with the proteasome inhibitor MG132 abolished the MPP+ induced cyclin D1 degradation. $\mathrm{MPP}^{+}$treatment resulted in the dephosphorylation of Akt and inhibition of GSK3 $\beta$ with $\mathrm{LiCl}$, also effectively abolished cyclin $\mathrm{D} 1$ degradation. $\mathrm{MPP}+$ thus induces the ubiquitin-dependent degradation of cyclin D1 in MG63 cells in a phosphorylation dependent manner [94]. The natural metabolites hypothemycin $(0.5 \mu \mathrm{g} / \mathrm{Ml})$ and $\mathrm{O}-$ methyl deoxybouvardin (RA-VII) $(100 \mathrm{nM})$ have also been shown to induce the ubiquitin-dependent degradation of cyclin D1 in transformed NIH3T3 mouse and human colon cancer cell lines respectively $[95,96]$. In both studies, inhibition of proteasomal activity by lactacystin abolished the effect of these compounds on cyclin D1 degradation. GL331 is a semi-synthetic podophyllotoxin derivative similar to etoposide (VP-16) $[97,98]$. Culture of CL1-5 human lung adenocarcinoma cells with 10 $\mu \mathrm{M}$ GL331 induced cyclin D1 degradation within $4 \mathrm{~h}$ of exposure and was sensitive to proteasome inhibition $(\mathrm{N}$ carbobenzyloxy-leucine-leucine-leucine-aldehyde, $\quad \mathrm{N}$ CBZ-L-L-L-AL) [99]. The role of T286 phosphorylation in mediating the degradation of cyclin D1 by hypothemycin, RA-VII and GL331 has not been reported. The phytochemical resveratrol is common in food products including red wine and inhibits cancer cell proliferation in vitro [100102]. Treatment of SW480 colon cancer cells with $300 \mu \mathrm{M}$ resveratrol induced effective clearance of cyclin D1 within $2 \mathrm{~h}$ and was inhibited by LLnL [103]. The effect of resveratrol on cyclin D1 degradation may be cell line specific since the cyclin was not degraded in HL60 promyelocytic leukaemia cells [104]. Diferuloylmethane (curcumin) is a chemopreventitive agent that inhibits the proliferation of a wide range of cancer cells $[105,106]$. Treatment of LnCap prostate cancer cells and various breast cancer cell 
lines with $25 \mu \mathrm{M}$ curcumin for $3 \mathrm{~h}$ resulted in a near-total loss of cyclin D1 expression [107]. Co-culture of curcumin with lactacystin abolished cyclin D1 degradation. The role of GSK3 $\beta$ in mediating curcumin induced cyclin D1 degradation however, remains unclear. Curcumin also strongly repressed the expression of cyclin D1 mRNA within 30-60 min in MCF-7 and LnCap cells [107]. The simultaneous repression of cyclin D1 expression and increased degradation at the protein level, partly explains the rapid effect of curcumin on cyclin D1 levels in these cells. Lovastatin inhibits 3-hydroxy-3-methylglutarylcoenzyme A reductase and has been shown to induce cell cycle arrest [108-110]. Treatment of PC-3-M prostate cancer cells with $10 \mu \mathrm{M}$ Lovastatin for $36 \mathrm{~h}$ induced cyclin D1 degradation. Lovastatin induced cyclin D1 degradation was inhibited by LLnL but not lactacystin [111]. Aspirin $[112,113]$ was recently reported to induce the p38 3 SAPK2 dependent degradation of cyclin D1 in SW480 and HT-29 colon cancer cells [114]. Treatment of SW480 cells with 5 $\mathrm{nmol} / \mathrm{L}$ aspirin induced complete clearance in about $1 \mathrm{~h}$. The effect of aspirin on cyclin D1 stability in HT-29 cells was less potent, inducing a partial reduction of protein levels within $4 \mathrm{~h}$. Aspirin induced cyclin D1 degradation was effectively inhibited by MG132. As expected, inhibition of p38 $8^{\text {SAPK2 }}$ activity abolished aspirin induced cyclin D1 degradation [114].

Cycloheximide inhibits protein synthesis by preventing peptide initiation and extension in ribosomes $[115,116]$. Although it is not a therapeutic agent, cycloheximide is commonly used in studies on protein stability and degradation. In most cell lines, cyclin D1 levels rapidly decline following the inhibition of protein synthesis with cycloheximide. MG132 effectively abolishes cyclin D1 degradation following the inhibition of protein synthesis $[8,26,27]$. Treatment of MCF-7 cells expressing cyclin D1 constructs lacking lysine residues with cycloheximide still resulted in a decline in protein levels [27]. This observation highlights the importance of ubiquitin independent degradation in regulating cyclin D1 stability.

The proliferator- activated receptor (PPAR) superfamily of nuclear receptors mediates cellular processes such as proliferation and differentiation (reviewed in [117-119]). Activation of the proliferator- activated receptor $\gamma(\operatorname{PPAR} \gamma)$ by 15 -deoxy- $\Delta^{12,14}$ prostaglandin $J_{2}$ (PGJ2) or synthetic ligands, inhibits tumour cell proliferation and induces the ubiquitin dependent degradation of cyclin D1 $[120,121]$. Treatment of MCF-7 cells with 5-20 $\mu \mathrm{M}$ PGJ2 or 30-40 $\mu \mathrm{M}$ or the thiazolidinedione based PPAR $\gamma$ agonist ciglitazone inhibited G1 to $S$ phase progression but not apoptosis. Following treatment with $30 \mu \mathrm{M}$ PGJ2 or $80 \mu \mathrm{M}$ ciglitazone, total cyclin D1 levels were reduced to undetectable levels between 3 and $15 \mathrm{~h}$ after addition of either compound [120]. Cyclin D1 degradation was inhibited by the proteasome inhibitor MG132 (carbobenzyloxy-leucyl-leucyl-leucinal, Z-LLL-CHO) and PSII but not calpain inhibitors and resulted in the accumulation of poly-ubiquitylated species. Indirect fluorescence microscopy analyses suggested that cyclin D1 accumulates in the cytoplasm of PGJ2 treated MCF-7 cells [120]. This study did not however, investigate the role of GSK3 $\beta$ in mediating PGJ2 or ciglitazone induced cyclin D1 degradation. Later studies by Huang et al., [28], have demonstrated that the effect of synthetic PPAR $\gamma$ agonists on cyclin D1 stability is independent of PPAR $\gamma$ activation. In this study, a related PPAR $\gamma$ agonist, troglitazone (at concentrations of $40 \mu \mathrm{M}$ ), induced cyclin D1 degradation in MCF-7 cells 12-18 h after exposure. Co treatment of MCF-7 cells with the PPAR $\gamma$ antagonist GW9662 did not suppress troglitazone induced cyclin D1 degradation. Furthermore, additional thiazolidinediones such as rosiglitazone and piolitazone did not affect cyclin D1 stability, while derivatives that have no effect on PPAR $\gamma$ activity still induced degradation. Similarly to ciglitazone [120], troglitazone induced cyclin D1 degradation was also sensitive to specific inhibition of $26 S$ proteasomes by MG132, lactacystin and epoxomicin. Troglitazone did not however, activate GSK3 $\beta$ or require the activity of this kinase to induce cyclin D1 degradation. Derivatives of ciglitazone and troglitazone $(\Delta 2-\mathrm{TG}$ and $\Delta 2-\mathrm{CG})$ that are inactive as PPAR $\gamma$ activators also induced cyclin D1 degradation. The effect of these derivatives on cyclin D1 stability was similar to that of their parent compounds with slightly enhanced potency. The modification and optimization of $\Delta 2$-TG structure (by substitution of the terminal hydroxyl moiety) has resulted in the synthesis of derivatives with improved potency, capable of inducing cyclin D1 degradation at concentrations as low as $5 \mu \mathrm{M}$ [80]. Taken together, the studies by Wang et al., Qin et al. and Huang et al., $[80,120,121]$ indicate that PGJ2 and some synthetic PPAR $\gamma$ agonists induce the ubiquitin-dependent degradation of cyclin D1 independently of GSK3 $\beta$ activity. Since $\Delta 2$-TG derivatives induce cyclin D1 degradation at low concentrations that are clinically achievable independently of PPAR $\gamma$ activation, Huang et al., [80] have suggested that these compounds may be particularly useful as a platform for developing therapeutic cyclin D1 ablative agents.

Mammalian target of rapamycin (mTOR) is a target of the phosphatidylinositol 3-Kinase (PI3K)/protein kinase B (PKB/Akt) pathway (reviewed in [121-126]) and plays a major role in coupling mitogenic stimuli to cell cycle progression. Rapamycin binds to FK506 binding protein 12 (FKBP12) to form a complex which binds to and inactivates mTOR [127-130]. mTOR regulates several cellular processes. Previous studies have shown that mTOR regulates protein synthesis by phosphorylating the $4 \mathrm{E}$ binding protein 1 (4E-BP1), which frees the eukaryotic initiation factor-4 (eIF-4F) to form a multi-subunit complex with 
eIF-4A, eIF-4B and eIF-4G. The formation of active eIF4 complexes results in an increase in the rate of translation of cyclin D1 mRNA and other regulators of G1- S phase progression [123]. Deregulated PKB/Akt activity is common in many cancers and results in mTOR mediated stimulation of G1-S phase progression. The activity of several anti-apoptotic proteins that promote cancer cell survival is also increased as a result of deregulated PKB/Akt activity [131-133]. Furthermore, the deregulation of mTOR activity is associated with the development of both solid and haematological malignancies (reviewed in [134]). PKB/ Akt and mTOR thus present important therapeutic targets for anti-cancer agents [135]. Rapamycin inhibits cellular proliferation and induces G1 arrest, partly by repressing the expression of cyclin D1 [136-139]. In addition to suppressing the translation of cyclin D1 mRNA [137], rapamycin also induces the ubiquitin-dependent degradation of cyclin D1 [136]. Treatment of MCF-7 cells with $100 \mathrm{nmol} / \mathrm{L}$ rapamycin resulted in an approximately $50 \%$ reduction in cyclin D1 levels. In MDA-MB-468 breast cancer cells which express lower levels of cyclin D1, treatment with this concentration of rapamycin reduced the level of cyclin D1 to near undetectable levels within $6 \mathrm{~h}$. Treatment with rapamycin also reduced the half life of cyclin D1 in MCF-7 and MDA-MB-468 cells by approximately 44 and $20 \%$ respectively. Inhibition of $26 \mathrm{~S}$ proteasomal activity with ALLN abolished rapamycin induced cyclin D1 degradation. Rapamycin also activated GSK3 $\beta$ although this was not accompanied by phosphorylation of serine 9 (Ser9). Inhibition of GSK3 $\beta$ in MCF-7 cells by LiCl, SB216763 and SB415286 abolished cyclin D1 degradation as effectively as ALLN. Similarly, an exogenously expressed cyclin D1 T286A mutant was refractory to rapamycin induced degradation [136]. Taken together, these findings demonstrate that rapamycin activates GSK3 $\beta$ and induces the phosphorylation dependent degradation of cyclin D1 via the ubiquitin pathway in breast cancer cell lines.

Histone deacetylase inhibitors (HDACIs) have shown potent selective activity as anti cancer agents both in vitro and in vivo [140-146]. Trichostatin A (TSA) is a prototype HDACI that has been shown to induce cyclin D1 degradation in human breast cancer and transformed rat kidney fibroblast cell lines. Treatment of MCF-7 cells with $1 \mu \mathrm{M}$ TSA induced complete cyclin D1 degradation within $6 \mathrm{~h}$ of drug addition [25]. Similar results were obtained in MDA-MB-231 and rat KNRK cells, although the effect of TSA on cyclin D1 stability was less pronounced in these cell lines [25,45]. A structurally unrelated HDACI, HCtoxin (HCT) also repressed cyclin D1 expression in MCF7 and MDA-MB-231 cells [25]. The induction of cyclin D1 degradation may thus be a general feature of HDACIs. TSA induced the accumulation of polyubiquitylated cyclin D1 species and the nuclear export of the recombinant wild type protein but not a T268A mutant. The proteasome inhibitors MG132, ALLN, lactacystin and NLVS (NIP-leu $3^{-}$ vinyl sulphone) all inhibited TSA induced cyclin D1 degradation to varying degrees in MCF-7 cells. The inhibition of calpain activity with ALLM (Calpain inhibitor II, Nacetyl-leucyl-leucyl-methional) or cathepsin activity did not affect TSA induced cyclin D1 degradation. TSA also induced accumulation of SKP2 in MCF-7 cells. Furthermore, the siRNA mediated knockdown of SKP2 delayed TSA induced cyclin D1 degradation [25]. The recent identification of bona fide E3 ligase complexes that target cyclin D1 suggests however, that SKP2 is not directly involved in the degradation of this cyclin $[8,9]$. It remains to be determined if SKP2 indirectly affects cyclin D1 stability in TSA treated MCF-7 cells. Inhibition of GSK3 $\beta$ activity with SB216763 or knockdown by siRNA partially inhibited cyclin D1 degradation. Similarly, inhibition of CRM1 mediated nuclear export with leptomycin B (LMB) also partially abolished TSA induced degradation. The ubiquitin-dependent degradation of cyclin D1 induced by TSA in MCF-7 cells is thus partially dependent on GSK3 $\beta$ activity [26]. HDACIs have also been shown to delay entry into mitosis by activating the p38 ${ }^{\mathrm{SAPK} 2}$ checkpoint [50]. Although osmotic stress has been shown to induce the p38 ${ }^{\text {SAPK2}-d e p e n d e n t ~ d e g r a d a t i o n ~ o f ~ c y c l i n ~ D 1, ~ t h e ~ r o l e ~ o f ~}$ p38 $8^{\text {APK2 }}$ in mediating HDAC induced cyclin D1 degradation remains to be investigated. HDACIs have recently been shown to sensitize cancer cells to the cytotoxic effects of conventional therapeutic agents [147-152]. The effect of HDACIs on cyclin D1 stability may underlie some of these effects. Deregulated cyclin D1 expression has been associated with resistance to endocrine and erbB therapies $[20-22,153,154]$. HDACIs may thus be clinically useful in overcoming drug resistance associated with cyclin D1 over expression.

Pharmacologically and structurally diverse compounds have been shown to induce cyclin D1 degradation. Little is known about how these compounds affect the stability of the cyclin D1b variant which lacks the c-terminal regulatory sequences. PPAR $\gamma$ activators and HDAC inhibitors have been shown to induce cyclin D1 degradation independently of T286 phosphorylation. These compounds may thus also be useful in the ablation of cyclin D1b levels.

\section{Unresolved questions}

The recent identification of SCF-complexes that mediate cyclin D1 degradation has greatly broadened the understanding of how the stability of this cyclin is regulated $[8,9]$. Prior studies suggest however, that additional mediators of cyclin D1 degradation exist [56]. Both SCFFBX4- $\alpha \mathrm{B}$ crystallin and FBXW8 specifically target T286 phosphorylated cyclin D1 for ubiquitin-dependent degradation. Cyclin D1 degradation can occur independently of T286 
phosphorylation and variants that lack threonine phosphorylation sites are still relatively unstable $[46,63]$. In MCF-7 cells, the expression of $\alpha \mathrm{B}$ crystallin is extremely low or absent [8]. None the less, inhibition of protein synthesis with cycloheximide still results in the fairly rapid decline of cyclin D1 levels [8]. Inhibition of GSK3 $\beta$ or CRM1 dependent nuclear export failed to abolish the rapid degradation of cyclin D1 [26]. Cyclin D1 can thus be effectively degraded even in the absence of SCFFBX4- $\alpha \mathrm{B}$ crystallin complexes. Several potential anti-cancer agents have been shown to induce cyclin D1 degradation via the proteasome (discussed above). The effects of these agents on

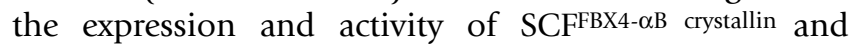
FBXW8 remains to be determined. SCFFBX4- $\alpha$ B crystallin expression is often lost in cancer cells as a result of chromosomal deletions [8]. It is thus unclear if drug induced cyclin D1 degradation is dependent on the expression of SCFFBX4- $\alpha \mathrm{B}$ crystallin, FBXW8 and other specific E3 ligases. PPAR $\gamma$ agonists and HDAC inhibitors effectively induce cyclin D1 degradation even in the absence of GSK3 $\beta$ activity $[26,28]$. Since SCFFBX4- $\alpha$ B crystallin and FBXW8 specifically target T286 phosphorylated cyclin D1, it is possible that the degradation induced by troglitazone and TSA occurs independently of these E3 ligases. The precise roles of both complexes in mediating cancer cell proliferation remain unclear. Knockdown of SCFFBX4- $\alpha$ B crystallin complexes by siRNA shortened progression into $\mathrm{S}$ phase following nocodazole release. Furthermore, SCFFBX4- $\alpha \mathrm{B}$ crystallin expression is frequently lost in cancer cell lines and primary cancers [8]. In direct contrast, siRNA mediated knockdown of FBXW8 complexes inhibited the proliferation of cancer cell lines [9]. SCFFBX4- $\alpha$ B crystallin and FBXW8 may thus regulate different aspects of phosphorylation dependent cyclin D1 degradation. It is also possible that while the loss of SCFFBX4- $\alpha$ B crystallin allows the accumulation of cyclin D1 during cancer development, the continued expression of FBXW8 is required to maintain levels below the threshold required to repress DNA replication $[38,43,54]$.

An early study suggested a role for calpains in regulating cyclin D1 stability [111]. In this study, LLnL and ALLM but not lactcystin inhibited serum starvation induced cyclin D1 loss in NIH 3T3 cells. Furthermore, lactacystin failed to abolish actinomycin D and lovastatin induced cyclin D1 loss in PC-3-M prostate cancer cells. For these reasons, cyclin D1 stability was initially assumed to be regulated by calpains (ref). MG132 completely abolished TSA induced cyclin D1 degradation in MCF-7 cells $[26,45]$. Lactacystin only partially inhibited TSA induced cyclin D1 degradation but completely abolished troglitazone induced cyclin D1 degradation [28]. The inhibition of protein synthesis with cycloheximide led to the rapid decline of cyclin D1 levels in MCF-7 cells. This loss of cyclin D1 expression was inhibited by MG132 but not lacta- cystin, SB216763 or LMB [26]. Ubiquitin-dependent degradation clearly plays an important role in regulating cyclin D1 stability $[8,9]$. It is possible however, that peptide aldehyde proteasome inhibitors like MG132 and LLnL block additional pathways that regulate cyclin D1 stability [155-157].

The SK-UT-1B cell line presents an interesting paradox. The ubiquitin-dependent degradation of cyclin D1 is defective in this cell line and lysates fail to mediate the polyubiquitylation of cyclin D1 in vitro $[46,158]$. In contrast to MCF-7 cells, the inhibition of protein synthesis did not lead to the rapid decline of cyclin D1 levels in SKUT-1B cells. Furthermore, cyclin D1 levels remained elevated even when the cells were arrested at the G1/S phase boundary with hydroxyurea [45]. These observations suggest that cyclin D1 levels do not decline during $\mathrm{S}$ phase in this cell line. The expression of a SKP2 splice variant which fails to migrate to the nucleus has been linked to defective proteolysis in SK-UT-1B cells [158], since expression of SKP2 rescued cyclin D1 degradation. Recent studies suggest however, that SKP2 is not a direct mediator of cyclin D1 degradation $[8,9]$. SK-UT-1B cells may thus harbour additional defects in pathways that regulate cyclin D1 degradation. The degradation of cyclin D1 at S phase facilitates DNA replication and cell cycle progression. In fact, deregulated cyclin D1 expression is known to inhibit cell proliferation and the generation of clones stably expressing the T286A mutant is somewhat difficult $[9,38,43,54]$. The question thus arises: how SK-UT-1B cells proliferate in the absence of cyclin D1 degradation? One possibility is that SK-UT-1B cells integrate the proliferative and anti-proliferative properties of cyclin D1 by means of cytoplasmic sequestration. In this model, cyclin D1 is retained in the cytoplasm and its nuclear import is dependent on its binding partners (CDK4, CDK6, p21, p27 and various transcription factors). At the same time, nuclear accumulation is tightly regulated by the continuous nuclear export of GSK3 $\beta$ phosphorylated cyclin D1 throughout the cell cycle $[44,45]$. The nuclear accumulation of cyclin D1 is thus limited by its continuous export which prevents PCNA and CDK2 inhibition. This would permit the effective replication of DNA in the absence of cyclin D1 degradation. The simultaneous inhibition of ubiquitin-dependent degradation and nuclear export did not result in the nuclear localization of cyclin D1 when its synthesis was inhibited in MCF-7 and SK-UT-1B cells [45]. The precise mechanism(s) that underlie the defective degradation of cyclin D1 in SK-UT-1B cells remains to be clearly defined. Such characterization could provide further insights into the regulation of cyclin D1 stability.

GSK3 $\beta$ activity appears to remain unchanged throughout the cell cycle and recent studies suggest a limited role for this kinase in mediating cyclin D1 degradation [44]. Inhi- 
bition of GSK3 $\beta$ can however, inhibit TSA induced cyclin D1 degradation and results in increased levels of the cyclin within the nucleus $[26,45]$. Changes to the accessibility of cyclin D1 during $S$ phase could also result in increased T286 phosphorylation in the absence of increased GSK3 $\beta$ activity $[43,44]$. If its major role does not involve regulating cyclin D1 stability, what then is the cellular function of GSK3 $\beta$ mediated T286 phosphorylation? The transforming activity of the T286A mutant and cyclin D1b seems to depend more on their constitutive nuclear localization, than on their stability or capacity to phosphorylate RB [63]. It is possible therefore, that GSK3 $\beta$ functions to regulate the levels of cyclin D1 within the nucleus. Cyclin D1 has been reported to be sequestered in the cytoplasm of post mitotic neurons [75]. The cytoplasmic sequestration of cyclin D1 may also present also a novel mechanism for regulating its activity in some cancer cell lines [45]. It remains to be seen, whether the concept of a predominantly cytoplasmic localization for cyclin D1 turns out to be a paradigm or a heresy.

\section{Conclusion}

Cyclin D1 is an important regulator of cell cycle progression and overexpression of cyclin D1 has been linked to the development and progression of cancer. Deregulated cyclin D1 expression is also linked to the development of resistance to hormone therapy in breast cancer. In many cancers, the impaired ubiquitin-dependent degradation of cyclin D1 is responsible for its elevated levels. A number of therapeutic agents have been shown to induce cyclin D1 degradation via the ubiquitin pathway. Drug induced cyclin D1 ablation may provide a useful chemopreventive or treatment strategy for cancer. The development of such agents requires a firm understanding of cyclin D1 regulation. Recent reports have increased our understanding of how cyclin D1 degradation is regulated. At present, a number of questions remain unanswered. These include the role of phosphorylation and/or ubiquitin-independent degradation, the effects of agents that induce cyclin D1 degradation on the stability and/or activity of cyclin D1b, SCFFBX4- $\alpha$ B crystallin and FBXW8, as well as the precise role of GSK3 $\beta$ in regulating cyclin D1 activity. Finally, the significance of cyclin D1 sequestration within the cytoplasm needs to be properly addressed. We can look forward to further exciting developments in this important area of cancer cell research in the coming years.

\section{Competing interests}

The author(s) declare that they have no competing interests.

\section{Authors' contributions}

JPA reviewed the literature, drafted and finalized the manuscript.

\section{Acknowledgements}

I thank especially, Profs. Peter Carlsson, Jeanette Nilson, Marc Pilon, and Per Sunnerhagen, for their critical reading of this manuscript and helpful commentary. JPA is funded by the European Molecular Biology Organization (EMBO) on a long-term postdoctoral fellowship. I apologise to those investigators whose work could not be included or was inadvertently omitted.

\section{References}

I. Kato J, Matsushime H, Hiebert SW, Ewen ME, Sherr CJ: Direct binding of cyclin $D$ to the retinoblastoma gene product ( $p R b)$ and pRb phosphorylation by the cyclin D-dependent kinase CDK4. Genes Dev 1993, 7(3):331-342.

2. Lundberg AS, Weinberg RA: Functional inactivation of the retinoblastoma protein requires sequential modification by at least two distinct cyclin-cdk complexes. Mol Cell Biol 1998, 18(2):753-76I.

3. Weinberg RA: The retinoblastoma protein and cell cycle control. Cell 1995, $81(3): 323-330$.

4. Coqueret O: Linking cyclins to transcriptional control. Gene 2002, 299(I-2):35-55.

5. Diehl JA, Cheng M, Roussel MF, Sherr CJ: Glycogen synthase kinase-3beta regulates cyclin DI proteolysis and subcellular localization. Genes Dev 1998, I2(22):3499-35II.

6. Diehl JA, Zindy F, Sherr CJ: Inhibition of cyclin DI phosphorylation on threonine-286 prevents its rapid degradation via the ubiquitin-proteasome pathway. Genes Dev 1997, II (8):957-972.

7. Yu ZK, Gervais JL, Zhang H: Human CUL-I associates with the SKPI/SKP2 complex and regulates $\mathrm{P} 2 \mathrm{I}(\mathrm{CIPI} / \mathrm{WAFI})$ and cyclin D proteins. Proc Natl Acad Sci U S A 1998, 95(19): I I324-II 329.

8. Lin DI, Barbash O, Kumar KG, Weber JD, Harper JW, Klein-Szanto A], Rustgi A, Fuchs SY, Diehl JA: Phosphorylation-dependent ubiquitination of cyclin DI by the SCF(FBX4-alphaB crystallin) complex. Mol Cell 2006, 24(3):355-366.

9. Okabe H, Lee SH, Phuchareon J, Albertson DG, McCormick F, Tetsu O: A Critical Role for FBXW8 and MAPK in Cyclin DI Degradation and Cancer Cell Proliferation. PLOS ONE 2006, I:e I 28.

10. Hall M, Peters G: Genetic alterations of cyclins, cyclin-dependent kinases, and Cdk inhibitors in human cancer. Adv Cancer Res 1996, 68:67-108.

II. Vermeulen K, Van Bockstaele DR, Berneman ZN: The cell cycle: a review of regulation, deregulation and therapeutic targets in cancer. Cell Prolif 2003, 36(3): I3I-I49.

12. Gillett C, Smith P, Gregory W, Richards M, Millis R, Peters G, Barnes $D:$ Cyclin DI and prognosis in human breast cancer. Int J Cancer 1996, 69(2):92-99.

13. Knudsen KE, Diehl JA, Haiman CA, Knudsen ES: Cyclin DI: polymorphism, aberrant splicing and cancer risk. Oncogene 2006, 25(II):1620-1628.

14. Motokura T, Arnold A: Cyclin D and oncogenesis. Curr Opin Genet Dev 1993, 3(I):5-10.

15. Musgrove EA: Cyclins: roles in mitogenic signaling and oncogenic transformation. Growth Factors 2006, 24(1):13-19.

16. Sicinski P, Donaher JL, Parker SB, Li T, Fazeli A, Gardner H, Haslam SZ, Bronson RT, Elledge SJ, Weinberg RA: Cyclin DI provides a link between development and oncogenesis in the retina and breast. Cell 1995, 82(4):62I-630.

17. Sutherland RL, Musgrove EA: Cyclin DI and mammary carcinoma: new insights from transgenic mouse models. Breast Cancer Res 2002, 4(I): 14-I7.

18. Weinstat-Saslow D, Merino MJ, Manrow RE, Lawrence JA, Bluth RF, Wittenbel KD, Simpson JF, Page DL, Steeg PS: Overexpression of cyclin D mRNA distinguishes invasive and in situ breast carcinomas from non-malignant lesions. Nat Med 1995, I(I2): I $257-1260$

19. Yamamoto M, Tamakawa S, Yoshie M, Yaginuma Y, Ogawa K: Neoplastic hepatocyte growth associated with cyclin DI redistribution from the cytoplasm to the nucleus in mouse hepatocarcinogenesis. Mol Carcinog 2006, 45(I 2):90I-9I3.

20. Hodges LC, Cook JD, Lobenhofer EK, Li L, Bennett L, Bushel PR, Aldaz CM, Afshari CA, Walker CL: Tamoxifen functions as a molecular agonist inducing cell cycle-associated genes in breast cancer cells. Mol Cancer Res 2003, I (4):300-3II. 
21. Hui R, Finney GL, Carroll JS, Lee CS, Musgrove EA, Sutherland RL: Constitutive overexpression of cyclin DI but not cyclin $E$ confers acute resistance to antiestrogens in T-47D breast cancer cells. Cancer Res 2002, 62(23):6916-6923.

22. Kenny FS, Hui R, Musgrove EA, Gee JM, Blamey RW, Nicholson RI, Sutherland RL, Robertson JF: Overexpression of cyclin DI messenger RNA predicts for poor prognosis in estrogen receptor-positive breast cancer. Clin Cancer Res 1999, 5(8):2069-2076.

23. Gillett C, Fantl V, Smith R, Fisher C, Bartek J, Dickson C, Barnes D, Peters G: Amplification and overexpression of cyclin DI in breast cancer detected by immunohistochemical staining. Cancer Res 1994, 54(7): 1812-1817.

24. Russell A, Thompson MA, Hendley J, Trute L, Armes J, Germain D: Cyclin DI and D3 associate with the SCF complex and are coordinately elevated in breast cancer. Oncogene 1999, I 8(I I): I983-199I.

25. Alao JP, Lam EW, Ali S, Buluwela L, Bordogna W, Lockey P, Varshochi R, Stavropoulou AV, Coombes RC, Vigushin DM: Histone deacetylase inhibitor trichostatin $A$ represses estrogen receptor alpha-dependent transcription and promotes proteasomal degradation of cyclin DI in human breast carcinoma cell lines. Clin Cancer Res 2004, I 0(23):8094-8I04.

26. Alao JP, Stavropoulou AV, Lam EW, Coombes RC, Vigushin DM: Histone deacetylase inhibitor, trichostatin $A$ induces ubiquitindependent cyclin DI degradation in MCF-7 breast cancer cells. Mol Cancer 2006, 5:8.

27. Feng Q, Sekula D, Muller R, Freemantle SJ, Dmitrovsky E: Uncovering residues that regulate cyclin $D I$ proteasomal degradation. Oncogene 2007.

28. Huang JW, Shiau CW, Yang YT, Kulp SK, Chen KF, Brueggemeier RW, Shapiro CL, Chen CS: Peroxisome proliferator-activated receptor gamma-independent ablation of cyclin $D I$ by thiazolidinediones and their derivatives in breast cancer cells. Mol Pharmacol 2005, 67(4): I 342-1348.

29. Langenfeld J, Kiyokawa H, Sekula D, Boyle J, Dmitrovsky E: Posttranslational regulation of cyclin DI by retinoic acid: a chemoprevention mechanism. Proc Natl Acad Sci U S A 1997 , 94(22): I 2070-I2074.

30. Spinella MJ, Freemantle SJ, Sekula D, Chang JH, Christie AJ, Dmitrovsky E: Retinoic acid promotes ubiquitination and proteolysis of cyclin DI during induced tumor cell differentiation. J Biol Chem 1999, 274(31):22013-22018.

31. Dragnev KH, Petty WJ, Dmitrovsky E: Retinoid targets in cancer therapy and chemoprevention. Cancer Biol Ther 2003, 2(4 Suppl I):SI50-6.

32. Yu Q, Geng Y, Sicinski P: Specific protection against breast cancers by cyclin DI ablation. Nature 2001, 41 I:1017-1021.

33. Baldin V, Lukas J, Marcote MJ, Pagano M, Draetta G: Cyclin D I is a nuclear protein required for cell cycle progression in $\mathrm{GI}$. Genes Dev 1993, 7(5):812-821.

34. Dowdy SF, Hinds PW, Louie K, Reed SI, Arnold A, Weinberg RA: Physical interaction of the retinoblastoma protein with human D cyclins. Cell I993, 73(3):499-5II.

35. Ewen ME, Sluss HK, Sherr CJ, Matsushime H, Kato J, Livingston DM: Functional interactions of the retinoblastoma protein with mammalian D-type cyclins. Cell 1993, 73(3):487-497.

36. Fu M, Wang C, Li Z, Sakamaki T, Pestell RG: Minireview: Cyclin DI: normal and abnormal functions. Endocrinology 2004, I 45( I 2):5439-5447

37. Hatakeyama M, Brill JA, Fink GR, Weinberg RA: Collaboration of $G I$ cyclins in the functional inactivation of the retinoblastoma protein. Genes Dev 1994, 8(I5): I759-I77I.

38. Fukami-Kobayashi J, Mitsui Y: Cyclin DI inhibits cell proliferation through binding to PCNA and cdk2. Exp Cell Res 1999, 246(2):338-347.

39. Pagano M, Theodoras AM, Tam SW, Draetta GF: Cyclin DI-mediated inhibition of repair and replicative DNA synthesis in human fibroblasts. Genes Dev I994, 8(I4): I627-1639.

40. Alt JR, Cleveland JL, Hannink M, Diehl JA: Phosphorylationdependent regulation of cyclin $D I$ nuclear export and cyclin DI-dependent cellular transformation. Genes Dev 2000, | 4(24):3 | 02-3| |4.

4I. Cross DA, Alessi DR, Vandenheede JR, McDowell HE, Hundal HS, Cohen $P$ : The inhibition of glycogen synthase kinase- 3 by insulin or insulin-like growth factor I in the rat skeletal muscle cell line $\mathbf{L 6}$ is blocked by wortmannin, but not by rapamycin: evidence that wortmannin blocks activation of the mitogenactivated protein kinase pathway in L6 cells between Ras and Raf. Biochem J 1994, 303 ( Pt I):21-26.

42. Saito $Y, V$ andenheede JR, Cohen P: The mechanism by which epidermal growth factor inhibits glycogen synthase kinase 3 in A43 I cells. Biochem J I994, 303 ( Pt I):27-3I.

43. Guo Y, Yang K, Harwalkar J, Nye JM, Mason DR, Garrett MD, Hitomi M, Stacey DW: Phosphorylation of cyclin DI at Thr 286 during $S$ phase leads to its proteasomal degradation and allows efficient DNA synthesis. Oncogene 2005, 24( I 6):2599-26I 2.

44. Yang K, Guo Y, Stacey WC, Harwalkar J, Fretthold J, Hitomi M, Stacey DW: Glycogen synthase kinase 3 has a limited role in cell cycle regulation of cyclin DI levels. BMC Cell Biol 2006, 7:33.

45. Alao JP, Gamble SC, Stavropoulou AV, Pomeranz KM, Lam EW, Coombes RC, Vigushin DM: The cyclin DI proto-oncogene is sequestered in the cytoplasm of mammalian cancer cell lines. Mol Cancer 2006, 5:7.

46. Germain D, Russell A, Thompson A, Hendley J: Ubiquitination of free cyclin $D I$ is independent of phosphorylation on threonine 286. J Biol Chem 2000, 275( I 6): I 2074- I 2079.

47. Zou Y, Ewton DZ, Deng X, Mercer SE, Friedman E: Mirk/dyrk IB kinase destabilizes cyclin $\mathrm{DI}$ by phosphorylation at threonine 288. I Biol Chem 2004, 279(26):27790-27798.

48. Agami R, Bernards $\mathrm{R}$ : Distinct initiation and maintenance mechanisms cooperate to induce $G I$ cell cycle arrest in response to DNA damage. Cell 2000, I 02(I):55-66.

49. Casanovas O, Miro F, Estanyol JM, Itarte E, Agell N, Bachs O: Osmotic stress regulates the stability of cyclin DI in a p38SAPK2-dependent manner. J Biol Chem 2000, 275(45):3509|-35097.

50. Mikhailov A, Shinohara M, Rieder CL: Topoisomerase II and histone deacetylase inhibitors delay the G2/M transition by triggering the p38 MAPK checkpoint pathway. J Cell Biol 2004, 166(4):517-526.

5I. Dmitrieva NI, Burg MB: Hypertonic stress response. Mutat Res 2005, 569( I-2):65-74.

52. Dmitrieva NI, Burg MB, Ferraris JD: DNA damage and osmotic regulation in the kidney. Am J Physiol Renal Physiol 2005, 289(I):F2-7.

53. Stacey DW: Cyclin DI serves as a cell cycle regulatory switch in actively proliferating cells. Curr Opin Cell Biol 2003, I5(2): | 58-163.

54. Yang K, Hitomi M, Stacey DW: Variations in cyclin DI levels through the cell cycle determine the proliferative fate of a cell. Cell Div 2006, 1:32.

55. Luo H, Zhang J, Dastvan F, Yanagawa B, Reidy MA, Zhang HM, Yang $D$, Wilson JE, McManus BM: Ubiquitin-dependent proteolysis of cyclin DI is associated with coxsackievirus-induced cell growth arrest. J Virol 2003, 77(I): I-9.

56. Newman RM, Mobascher A, Mangold U, Koike C, Diah S, Schmidt M, Finley D, Zetter BR: Antizyme targets cyclin DI for degradation. A novel mechanism for cell growth repression. J Biol Chem 2004, 279(40):4I504-4I5II.

57. Fong LY, Feith DJ, Pegg AE: Antizyme overexpression in transgenic mice reduces cell proliferation, increases apoptosis, and reduces $\mathbf{N}$-nitrosomethylbenzylamine-induced forestomach carcinogenesis. Cancer Res 2003, 63( I 4):3945-3954.

58. Iwata S, Sato Y, Asada M, Takagi M, Tsujimoto A, Inaba T, Yamada T, Sakamoto S, Yata J, Shimogori T, Igarashi K, Mizutani S: Anti-tumor activity of antizyme which targets the ornithine decarboxylase (ODC) required for cell growth and transformation. Oncogene 1999, I8(I): I65-172.

59. Tsuji T, Usui S, Aida T, Tachikawa T, Hu GF, Sasaki A, Matsumura T, Todd R, Wong DT: Induction of epithelial differentiation and DNA demethylation in hamster malignant oral keratinocyte by ornithine decarboxylase antizyme. Oncogene 2001, 20(I):24-33.

60. Betticher DC, Thatcher N, Altermatt HJ, Hoban P, Ryder WD, Heighway J: Alternate splicing produces a novel cyclin DI transcript. Oncogene 1995, I I(5): I005-I0II.

61. Hosokawa Y, Gadd M, Smith AP, Koerner FC, Schmidt EV, Arnold A: Cyclin DI (PRADI) alternative transcript b: full-length cDNA cloning and expression in breast cancers. Cancer Lett I997, I | 3( I-2): | 23-130. 
62. Lu F, Gladden AB, Diehl JA: An alternatively spliced cyclin D I isoform, cyclin DIb, is a nuclear oncogene. Cancer Res 2003, 63(2I):7056-706I.

63. Solomon DA, Wang Y, Fox SR, Lambeck TC, Giesting S, Lan Z, Senderowicz AM, Conti CJ, Knudsen ES: Cyclin DI splice variants. Differential effects on localization, RB phosphorylation, and cellular transformation. J Biol Chem 2003, 278(32):30339-30347.

64. Burd CJ, Petre CE, Morey LM, Wang Y, Revelo MP, Haiman CA, Lu S, Fenoglio-Preiser CM, Li J, Knudsen ES, Wong J, Knudsen KE: Cyclin DIb variant influences prostate cancer growth through aberrant androgen receptor regulation. Proc Natl Acad Sci U S A 2006, 103(7):2190-2195.

65. Knudsen KE: The cyclin DIb splice variant: an old oncogene learns new tricks. Cell Div 2006, I:I5.

66. Deshaies RJ: SCF and Cullin/Ring H2-based ubiquitin ligases. Annu Rev Cell Dev Biol 1999, 15:435-467.

67. Hermand D: F-box proteins: more than baits for the SCF? Cell Div 2006, I:30.

68. Petroski MD, Deshaies RJ: Mechanism of lysine 48-linked ubiquitin-chain synthesis by the cullin-RING ubiquitin-ligase complex SCF-Cdc34. Cell 2005, I 23(6): I I07-I I 20.

69. Petroski MD, Deshaies RJ: In vitro reconstitution of SCF substrate ubiquitination with purified proteins. Methods Enzymol 2005, 398: $143-158$

70. Seol JH, Feldman RM, Zachariae W, Shevchenko A, Correll CC, Lyapina S, Chi Y, Galova M, Claypool J, Sandmeyer S, Nasmyth K, Deshaies RJ, Shevchenko A, Deshaies RJ: Cdc53/cullin and the essential HrtI RING-H2 subunit of SCF define a ubiquitin ligase module that activates the E2 enzyme Cdc34. Genes Dev 1999, I3(12):1614-1626.

7I. Abdolzade-Bavil A, Hayes S, Goretzki L, Kroger M, Anders J, Hendriks R: Convenient and versatile subcellular extraction procedure, that facilitates classical protein expression profiling and functional protein analysis. Proteomics 2004, 4(5): $1397-1405$

72. Chung JH, Eng C: Nuclear-cytoplasmic partitioning of phosphatase and tensin homologue deleted on chromosome 10 (PTEN) differentially regulates the cell cycle and apoptosis. Cancer Res 2005, 65( ( 8):8096-8100.

73. Krieger S, Gauduchon J, Roussel M, Troussard X, Sola B: Relevance of cyclin DIb expression and CCNDI polymorphism in the pathogenesis of multiple myeloma and mantle cell lymphoma. BMC Cancer 2006, 6:238.

74. Radu A, Neubauer V, Akagi T, Hanafusa H, Georgescu MM: PTEN induces cell cycle arrest by decreasing the level and nuclear localization of cyclin DI. Mol Cell Biol 2003, 23(17):6|39-6I49.

75. Sumrejkanchanakij P, Tamamori-Adachi M, Matsunaga $Y$, Eto K, lkeda MA: Role of cyclin DI cytoplasmic sequestration in the survival of postmitotic neurons. Oncogene 2003, 22(54):8723-8730.

76. Tamamori-Adachi M, Ito H, Sumrejkanchanakij P, Adachi S, Hiroe M, Shimizu M, Kawauchi J, Sunamori M, Marumo F, Kitajima S, Ikeda MA: Critical role of cyclin DI nuclear import in cardiomyocyte proliferation. Circ Res 2003, 92(I):el2-9.

77. Alt JR, Gladden AB, Diehl JA: p2I(CipI) Promotes cyclin DI nuclear accumulation via direct inhibition of nuclear export. | Biol Chem 2002, 277( ( 0):85 17-8523.

78. Smirnova IV, Bittel DC, Ravindra R, Jiang $H$, Andrews GK: Zinc and cadmium can promote rapid nuclear translocation of metal response element-binding transcription factor-I. J Biol Chem 2000, 275(13):9377-9384.

79. Dragnev KH, Feng Q, Ma Y, Shah SJ, Black C, Memoli V, Nugent W, Rigas JR, Kitareewan S, Freemantle S, Dmitrovsky E: Uncovering novel targets for cancer chemoprevention. Recent Results Cancer Res 2007, 174:235-243.

80. Huang JW, Shiau CW, Yang J, Wang DS, Chiu HC, Chen CY, Chen CS: Development of small-molecule cyclin DI-ablative agents. I Med Chem 2006, 49(I 5):4684-4689.

8I. Blomhoff R, Blomhoff HK: Overview of retinoid metabolism and function. J Neurobiol 2006, 66(7):606-630.

82. Lefebvre P, Martin PJ, Flajollet S, Dedieu S, Billaut X, Lefebvre B: Transcriptional activities of retinoic acid receptors. Vitam Horm 2005, 70: 199-264.

83. Boyle JO, Langenfeld J, Lonardo F, Sekula D, Reczek P, Rusch V, Dawson MI, Dmitrovsky E: Cyclin D I proteolysis: a retinoid chemoprevention signal in normal, immortalized, and transformed human bronchial epithelial cells. I Natl Cancer Inst 1999, 9l(4):373-379.

84. Mori J, Takahashi-Yanaga F, Miwa Y, Watanabe $Y$, Hirata M, Morimoto S, Shirasuna K, Sasaguri T: Differentiation-inducing factor-I induces cyclin DI degradation through the phosphorylation of Thr286 in squamous cell carcinoma. Exp Cell Res 2005, 310(2):426-433.

85. Takahashi-Yanaga F, Mori J, Matsuzaki E, Watanabe Y, Hirata M, Miwa Y, Morimoto S, Sasaguri T: Involvement of GSK-3beta and DYRKIB in differentiation-inducing factor-3-induced phosphorylation of cyclin DI in HeLa cells. J Biol Chem 2006, 28 I (50):38489-38497.

86. Takahashi-Yanaga F, Taba $Y$, Miwa $Y$, Kubohara $Y$, Watanabe $Y$, Hirata M, Morimoto S, Sasaguri T: Dictyostelium differentiationinducing factor-3 activates glycogen synthase kinase-3beta and degrades cyclin DI in mammalian cells. J Biol Chem 2003, 278(II):9663-9670.

87. Morris HR, Masento MS, Taylor GW, Jermyn KA, Kay RR: Structure elucidation of two differentiation inducing factors (DIF-2 and DIF-3) from the cellular slime mould Dictyostelium discoideum. Biochem J 1988, 249(3):903-906.

88. Morris HR, Taylor GW, Masento MS, Jermyn KA, Kay RR: Chemical structure of the morphogen differentiation inducing factor from Dictyostelium discoideum. Nature 1987, 328(6I33):8II-8I4.

89. Di Monte D, Jewell SA, Ekstrom G, Sandy MS, Smith MT: I-Methyl4-phenyl-I,2,3,6-tetrahydropyridine (MPTP) and I-methyl4-phenylpyridine (MPP+) cause rapid ATP depletion in isolated hepatocytes. Biochem Biophys Res Commun 1986, 137(1):310-315.

90. Miyako K, Kai Y, Irie T, Takeshige K, Kang D: The content of intracellular mitochondrial DNA is decreased by I-methyl-4-phenylpyridinium ion (MPP+). J Biol Chem 1997, 272(15):9605-9608.

9I. Soldner F, Weller M, Haid S, Beinroth S, Miller SW, Wullner U, Davis RE, Dichgans J, Klockgether T, Schulz JB: MPP+ inhibits proliferation of PCI 2 cells by a P2 I(WAFI/Cip I)-dependent pathway and induces cell death in cells lacking P2I(WAFI/CipI). Exp Cell Res 1999, 250(I):75-85.

92. Bloem BR, Irwin I, Buruma OJ, Haan J, Roos RA, Tetrud JW, Langston JW: The MPTP model: versatile contributions to the treatment of idiopathic Parkinson's disease. J Neurol Sci 1990, 97(23):273-293.

93. Langston JW, Irwin I: MPTP: current concepts and controversies. Clin Neuropharmacol 1986, 9(6):485-507.

94. Bai J, Nakamura H, Ueda S, Kwon YW, Tanaka T, Ban S, Yodoi J: Proteasome-dependent degradation of cyclin $D I$ in I-methyl-4phenylpyridinium ion (MPP+)-induced cell cycle arrest. J Biol Chem 2004, 279(37):387I0-387|4.

95. Sonoda H, Omi K, Hojo K, Nishida K, Omura S, Sugita K: Suppression of oncogenic transformation by hypothemycin associated with accelerated cyclin DI degradation through ubiquitin-proteasome pathway. Life Sci I999, 65(4):38I-394.

96. Wakita K, Minami M, Venkateswarlu A, Sharma VM, Ramesh M, Akahane K: Antitumor bicyclic hexapeptide RA-VII modulates cyclin DI protein level. Anticancer Drugs 200I, I 2(5):433-439.

97. Chang JY, Han FS, Liu SY, Wang ZQ, Lee KH, Cheng YC: Effect of 4 beta-arylamino derivatives of 4'-O-demethylepipodophyllotoxin on human DNA topoisomerase II, tubulin polymerization, KB cells, and their resistant variants. Cancer Res I99I, 5 I (7): I755-1759.

98. Huang TS, Lee CC, Chao Y, Shu CH, Chen LT, Chen LL, Chen MH, Yuan CC, Whang-Peng J: A novel podophyllotoxin-derived compound GL33I is more potent than its congener VP-I 6 in killing refractory cancer cells. Pharm Res 1999, 16(7):997-1002.

99. Lin S, Huang HC, Chen LL, Lee CC, Huang TS: GL33I induces down-regulation of cyclin $D I$ expression via enhanced proteolysis and repressed transcription. Mol Pharmacol 200I, 60(4):768-775.

100. Baur JA, Sinclair DA: Therapeutic potential of resveratrol: the in vivo evidence. Nat Rev Drug Discov 2006, 5(6):493-506.

10I. Fulda S, Debatin KM: Resveratrol modulation of signal transduction in apoptosis and cell survival: a mini-review. Cancer Detect Prev 2006, 30(3):217-223.

102. Jang M, Cai L, Udeani GO, Slowing KV, Thomas CF, Beecher CW, Fong HH, Farnsworth NR, Kinghorn AD, Mehta RG, Moon RC, Pezzuto JM: Cancer chemopreventive activity of resveratrol, a 
natural product derived from grapes. Science 1997, 275(5297):2।8-220.

103. Joe AK, Liu H, Suzui M, Vural ME, Xiao D, Weinstein IB: Resveratrol induces growth inhibition, S-phase arrest, apoptosis, and changes in biomarker expression in several human cancer cell lines. Clin Cancer Res 2002, 8(3):893-903.

104. Ragione FD, Cucciolla V, Borriello A, Pietra VD, Racioppi L, Soldati G, Manna C, Galletti P, Zappia V: Resveratrol arrests the cell division cycle at S/G2 phase transition. Biochem Biophys Res Commun 1998, 250(I):53-58.

105. Sharma RA, Gescher AJ, Steward WP: Curcumin: the story so far. Eur J Cancer 2005, 4 I( I 3): I955-1968.

106. Thangapazham RL, Sharma A, Maheshwari RK: Multiple molecular targets in cancer chemoprevention by curcumin. Aaps J 2006, 8(3):E443-9.

107. Mukhopadhyay A, Banerjee S, Stafford LJ, Xia C, Liu M, Aggarwal BB: Curcumin-induced suppression of cell proliferation correlates with down-regulation of cyclin DI expression and CDK4-mediated retinoblastoma protein phosphorylation. Oncogene 2002, 2 I(57):8852-886I.

108. Alberts AW, Chen J, Kuron G, Hunt V, Huff J, Hoffman C, Rothrock J, Lopez M, Joshua H, Harris E, Patchett A, Monaghan R, Currie S, Stapley E, Albers-Schonberg G, Hensens O, Hirshfield J, Hoogsteen K, Liesch J, Springer J: Mevinolin: a highly potent competitive inhibitor of hydroxymethylglutaryl-coenzyme $\mathbf{A}$ reductase and a cholesterol-lowering agent. Proc Natl Acad Sci U S A 1980, 77(7):3957-3961.

109. Keyomarsi K, Sandoval L, Band V, Pardee AB: Synchronization of tumor and normal cells from $\mathrm{GI}$ to multiple cell cycles by lovastatin. Cancer Res I99I, 5 I ( I3):3602-3609.

110. Poon RY, Toyoshima H, Hunter T: Redistribution of the CDK inhibitor p27 between different cyclin. CDK complexes in the mouse fibroblast cell cycle and in cells arrested with lovastatin or ultraviolet irradiation. Mol Biol Cell I 995, 6(9): I I97- I2 I3.

II I. Choi YH, Lee SJ, Nguyen P, Jang JS, Lee J, Wu ML, Takano E, Maki M, Henkart PA, Trepel JB: Regulation of cyclin DI by calpain protease. J Biol Chem 1997, 272(45):28479-28484.

112. Collier HO: New light on how aspirin works. Nature 1969, 223(520I):35-37.

113. Collier HO: A pharmacological analysis of aspirin. Adv Pharmacol Chemother 1969, 7:333-405.

114. Thoms HC, Dunlop MG, Stark LA: p38-mediated inactivation of cyclin DI/cyclin-dependent kinase 4 stimulates nucleolar translocation of ReIA and apoptosis in colorectal cancer cells. Cancer Res 2007, 67(4):1660-1669.

115. Baliga BS, Pronczuk AW, Munro HN: Mechanism of cycloheximide inhibition of protein synthesis in a cell-free system prepared from rat liver. J Biol Chem 1969, 244( (16):4480-4489.

116. Obrig TG, Culp WJ, McKeehan WL, Hardesty B: The mechanism by which cycloheximide and related glutarimide antibiotics inhibit peptide synthesis on reticulocyte ribosomes. J Biol Chem 197I, 246(I): I74-I8I.

117. Kota BP, Huang TH, Roufogalis BD: An overview on biological mechanisms of PPARs. Pharmacol Res 2005, 5 I (2):85-94.

118. Qi C, Zhu Y, Reddy JK: Peroxisome proliferator-activated receptors, coactivators, and downstream targets. Cell Biochem Biophys 2000, 32 Spring: 187-204.

119. Wang T, Xu J, Yu X, Yang R, Han ZC: Peroxisome proliferatoractivated receptor gamma in malignant diseases. Crit Rev Oncol Hematol 2006, 58(I): I-I4.

120. Qin C, Burghardt R, Smith R, Wormke M, Stewart J, Safe S: Peroxisome proliferator-activated receptor gamma agonists induce proteasome-dependent degradation of cyclin DI and estrogen receptor alpha in MCF-7 breast cancer cells. Cancer Res 2003, 63(5):958-964.

121. Wang C, Fu M, D'Amico M, Albanese C, Zhou JN, Brownlee M, Lisanti MP, Chatterjee VK, Lazar MA, Pestell RG: Inhibition of cellular proliferation through IkappaB kinase-independent and peroxisome proliferator-activated receptor gammadependent repression of cyclin DI. Mol Cell Biol 200I, 2 I (9):3057-3070.

122. Gingras AC, Raught B, Sonenberg N: mTOR signaling to translation. Curr Top Microbiol Immunol 2004, 279: 169-197.

123. Hay N, Sonenberg N: Upstream and downstream of mTOR. Genes Dev 2004, I 8( I6): 1926-1945.
124. Mamane Y, Petroulakis E, LeBacquer O, Sonenberg N: mTOR, translation initiation and cancer. Oncogene 2006, 25(48):6416-6422.

125. Mita MM, Mita A, Rowinsky EK: Mammalian target of rapamycin: a new molecular target for breast cancer. Clin Breast Cancer 2003, 4(2): I26-137.

126. Petroulakis E, Mamane $\mathrm{Y}$, Le Bacquer O, Shahbazian D, Sonenberg N mTOR signaling: implications for cancer and anticancer therapy. Br J Cancer 2006, 94(2): 195-199.

127. Brown EJ, Albers MW, Shin TB, Ichikawa K, Keith CT, Lane WS, Schreiber SL: A mammalian protein targeted by GI-arresting rapamycin-receptor complex. Nature 1994 369(6483):756-758.

128. Chiu MI, Katz H, Berlin V: RAPTI, a mammalian homolog of yeast Tor, interacts with the FKBPI2/rapamycin complex. Proc Natl Acad Sci U S A 1994, 9 I(26): | 2574- 12578.

129. Sabatini DM, Erdjument-Bromage H, Lui M, Tempst P, Snyder SH: RAFTI: a mammalian protein that binds to FKBPI 2 in a rapamycin-dependent fashion and is homologous to yeast TORs. Cell I994, 78(I):35-43.

130. Wiederrecht GJ, Sabers CJ, Brunn GJ, Martin MM, Dumont FJ, Abraham RT: Mechanism of action of rapamycin: new insights into the regulation of GI-phase progression in eukaryotic cells. Prog Cell Cycle Res 1995, I:53-7I.

13I. Datta SR, Brunet A, Greenberg ME: Cellular survival: a play in three Akts. Genes Dev 1999, I3(22):2905-2927.

132. Shaw RJ, Cantley LC: Ras, PI(3)K and mTOR signalling controls tumour cell growth. Nature 2006, 44 I (7092):424-430.

133. Woodgett JR: Recent advances in the protein kinase B signaling pathway. Curr Opin Cell Biol 2005, I7(2): I50-157.

134. Janus A, Robak T, Smolewski P: The mammalian target of the rapamycin (mTOR) kinase pathway: its role in tumourigenesis and targeted antitumour therapy. Cell Mol Biol Lett 2005, 10(3):479-498.

135. Carraway H, Hidalgo M: New targets for therapy in breast cancer: mammalian target of rapamycin (MTOR) antagonists. Breast Cancer Res 2004, 6(5):219-224.

136. Dong J, Peng J, Zhang H, Mondesire WH, Jian W, Mills GB, Hung MC, Meric-Bernstam F: Role of glycogen synthase kinase 3beta in rapamycin-mediated cell cycle regulation and chemosensitivity. Cancer Res 2005, 65(5): $1961-1972$

137. Hashemolhosseini S, Nagamine Y, Morley SJ, Desrivieres S, Mercep L, Ferrari S: Rapamycin inhibition of the $G I$ to $S$ transition is mediated by effects on cyclin DI mRNA and protein stability. I Biol Chem 1998, 273(23): | 4424- 44429.

138. Mondesire WH, Jian W, Zhang H, Ensor J, Hung MC, Mills GB, MericBernstam F: Targeting mammalian target of rapamycin synergistically enhances chemotherapy-induced cytotoxicity in breast cancer cells. Clin Cancer Res 2004, I0(20):703I-7042.

139. Noh WC, Mondesire WH, Peng J, Jian W, Zhang H, Dong J, Mills GB, Hung MC, Meric-Bernstam F: Determinants of rapamycin sensitivity in breast cancer cells. Clin Cancer Res 2004, 10(3): 1013-1023

140. Johnstone RW: Histone-deacetylase inhibitors: novel drugs for the treatment of cancer. Nat Rev Drug Discov 2002, I (4):287-299.

14I. Vigushin DM, Ali S, Pace PE, Mirsaidi N, Ito K, Adcock I, Coombes RC: Trichostatin $A$ is a histone deacetylase inhibitor with potent antitumor activity against breast cancer in vivo. Clin Cancer Res 200I, 7(4):97I-976.

142. Vigushin DM, Coombes RC: Histone deacetylase inhibitors in cancer treatment. Anticancer Drugs 2002, I3(I): I-I3.

143. Dokmanovic M, Marks PA: Prospects: histone deacetylase inhibitors. J Cell Biochem 2005, 96(2):293-304.

144. Johnstone RW, Licht JD: Histone deacetylase inhibitors in cancer therapy: is transcription the primary target? Cancer Cell 2003, 4(I): 13-18.

145. Marks PA, Jiang $X$ : Histone deacetylase inhibitors in programmed cell death and cancer therapy. Cell Cycle 2005, 4(4):549-55।.

146. Minucci S, Pelicci PG: Histone deacetylase inhibitors and the promise of epigenetic (and more) treatments for cancer. Nat Rev Cancer 2006, 6(I):38-5I.

147. Camphausen K, Burgan W, Cerra M, Oswald KA, Trepel JB, Lee M], Tofilon PJ: Enhanced radiation-induced cell killing and prolongation of gammaH2AX foci expression by the histone deacetylase inhibitor MS-275. Cancer Res 2004, 64(I):316-32I. 
148. Camphausen K, Cerna D, Scott T, Sproull M, Burgan WE, Cerra MA, Fine $\mathrm{H}$, Tofilon PJ: Enhancement of in vitro and in vivo tumor cell radiosensitivity by valproic acid. Int J Cancer 2005, I | 4(3):380-386

149. Camphausen K, Scott T, Sproull M, Tofilon PJ: Enhancement of xenograft tumor radiosensitivity by the histone deacetylase inhibitor MS-275 and correlation with histone hyperacetylation. Clin Cancer Res 2004, I 0 ( I 8 Pt I):6066-607I.

150. Kim IA, Shin JH, Kim IH, Kim JH, Kim JS, Wu HG, Chie EK, Ha SW Park $\mathrm{Cl}$, Kao GD: Histone deacetylase inhibitor-mediated radiosensitization of human cancer cells: class differences and the potential influence of p53. Clin Cancer Res 2006, I 2(3 Pt I):940-949.

I5I. Kim JH, Shin JH, Kim IH: Susceptibility and radiosensitization of human glioblastoma cells to trichostatin A, a histone deacetylase inhibitor. Int J Radiat Oncol Biol Phys 2004, 59(4): II74-II80.

152. Kim MS, Blake M, Baek JH, Kohlhagen G, Pommier Y, Carrier F: Inhibition of histone deacetylase increases cytotoxicity to anticancer drugs targeting DNA. Cancer Res 2003, 63(2I):729I-7300.

153. Ali S, Coombes RC: Endocrine-responsive breast cancer and strategies for combating resistance. Nat Rev Cancer 2002, 2(2): $|0|-\mid 12$.

154. Caldon CE, Daly RJ, Sutherland RL, Musgrove EA: Cell cycle control in breast cancer cells. I Cell Biochem 2006, 97(2):26I-274.

155. Cotelle V, Meek SE, Provan F, Milne FC, Morrice N, MacKintosh C: 14-3-3s regulate global cleavage of their diverse binding partners in sugar-starved Arabidopsis cells. Embo J 2000, I 9( I 2):2869-2876.

156. Kisselev AF, Goldberg AL: Proteasome inhibitors: from research tools to drug candidates. Chem Biol 200I, 8(8):739-758.

157. Lee DH, Goldberg AL: Proteasome inhibitors: valuable new tools for cell biologists. Trends Cell Biol I998, 8(1 0):397-403.

158. Ganiatsas S, Dow R, Thompson A, Schulman B, Germain D: A splice variant of Skp2 is retained in the cytoplasm and fails to direct cyclin DI ubiquitination in the uterine cancer cell line SKUT. Oncogene 200I, 20(28):364I-3650.

159. LaBaer J, Garrett MD, Stevenson LF, Slingerland JM, Sandhu C, Chou HS, Fattaey A, Harlow E: New functional actvities for the p2 I family of CDK inhibitors. Genes and Development 1997, I I ( I 2):847-862.

160. Cheng M, Olivier P, Diehl JA, Fero M, Roussel MF, Roberts JM, Sherr C): The p2 I(Cip I) and p27(Kip I) CDK 'inhibitors' are essential activators of cyclin D-dependent kinases in murine fibroblasts. Embo J 1999, 18(6): |57|-1583.

161. Diehl JA, Sherr C]: A dominant-negative cyclin DI mutant prevents nuclear import of cyclin-dependent kinase 4 (CDK4) and its phosphorylation by CDK-activating kinase. Mol Cell Biol 1997, I 7(I 2):7362-7374.

\section{Publish with Biomed Central and every scientist can read your work free of charge}

"BioMed Central will be the most significant development for disseminating the results of biomedical research in our lifetime. "

Sir Paul Nurse, Cancer Research UK

Your research papers will be:

- available free of charge to the entire biomedical community

- peer reviewed and published immediately upon acceptance

- cited in PubMed and archived on PubMed Central

- yours - you keep the copyright

Submit your manuscript here:

http://www.biomedcentral.com/info/publishing_adv.asp
BiolMedcentral 